\title{
EXCHANGE RATE PASS-THROUGH IN NEW MEMBER STATES \\ AND CANDIDATE COUNTRIES OF THE EU
}

Bamon Maria-Dolores

Documentos de Trabajo N. 0822

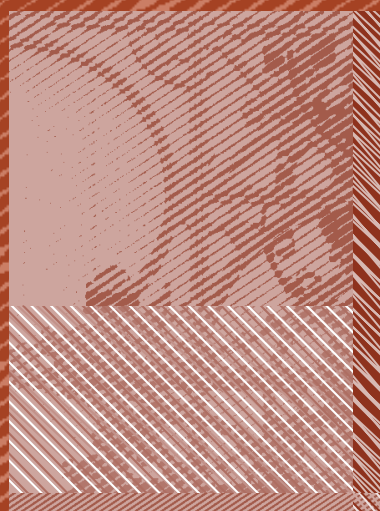

\section{BANCOTESPANA}

\author{
Eurosistema
}


EXCHANGE RATE PASS-THROUGH IN NEW MEMBER STATES

AND CANDIDATE COUNTRIES OF THE EU 
EXCHANGE RATE PASS-THROUGH IN NEW MEMBER STATES

AND CANDIDATE COUNTRIES OF THE EU ${ }^{(*)}$

\author{
Ramón María-Dolores ${ }^{(*)}$ \\ BANCO DE ESPAÑA AND UNIVERSIDAD DE MURCIA
}

(*) This paper was prepared while the author was visiting Bank of Spain. I am grateful to José Manuel Campa, José Manuel González-Mínguez, an anonymous referee and seminar participants at the Bank of Spain and UAM by their useful comments.

$\left.{ }^{* *}\right)$ Correspondence to: Ramón María-Dolores, Departamento de Fundamentos del Análisis Económico, Universidad de Murcia, Campus de Espinardo 30100, Spain. Phone: (34) 968-36-7908, Fax: (34) 968-36-3758, e-mail: ramonmar@um.es. 
The Working Paper Series seeks to disseminate original research in economics and finance. All papers have been anonymously refereed. By publishing these papers, the Banco de España aims to contribute to economic analysis and, in particular, to knowledge of the Spanish economy and its international environment.

The opinions and analyses in the Working Paper Series are the responsibility of the authors and, therefore, do not necessarily coincide with those of the Banco de España or the Eurosystem.

The Banco de España disseminates its main reports and most of its publications via the INTERNET at the following website: http://www.bde.es.

Reproduction for educational and non-commercial purposes is permitted provided that the source is acknowledged.

(C) BANCO DE ESPAÑA, Madrid, 2008

ISSN: 0213-2710 (print)

ISSN: 1579-8666 (on line)

Depósito legal:

Unidad de Publicaciones, Banco de España 


\section{Abstract}

This paper studies the pass-through of exchange rate changes into the prices of imports that originated inside the euro area made by some New Member States (NMSs) of the European Union and one candidate country (Turkey). I use data on import unit values for nine different product categories and bilateral imports from the euro area for each country and I estimate industry-specific rates of pass-through across and within countries using two different methodological approaches. The first one is based on Campa and González-Mínguez (2006) which estimates the short- and long-run pass through elasticities, where long-run elasticities are defined as the sum of the pass-through coefficients for the contemporaneous exchange rate and its first four lags. The second one is employed by de Bandt, Banerjee and Kozluk (2007) which suggests a long-run Engle and Granger (1987) cointegrating relationship and the possibility of structural breaks to restore the long-run in the estimation. I did not find evidence either in favour of the hypothesis of Local Currency Pricing (zero pass-through) or the hypothesis of Producer Currency Pricing (complete pass-through) for all the countries except Slovenia and Cyprus in the latter. The exchange rate pass-through ranged from 0.090 to 2.916 in the short-run and from 0.102 to 2.242 in the long-run. With reference to the results by industry the lowest values for exchange rate pass-through are in Manufacturing sectors. However, I did observe a exchange rate pass-through decline through the pricing chain and a large dependence of their economies on imported inputs.

Keywords: exchange rates, pass-through, monetary union, panel cointegration.

JEL classification numbers: F31, F36, F42, C23 


\section{INTRODUCTION}

The extent to which exchange rate changes are eventually reflected in import prices is commonly referred in the economic literature as the degree of exchange rate pass-through (ERPT). Therefore, imported goods are made up of a heterogeneous range of products and commodities and the pass-through may vary considerably across the different types of imports. For instance, where the law of one price may hold, one might expect a higher degree of pass-through for more homogeneous and widely traded goods and commodities, such as oil or raw materials than for highly differentiated manufactured products. In economic literature, where the law of one price holds and with a perfect pass-through, pricing of imports goods are assumed to be governed by Producer Currency Pricing (PCP). By contrast, a Local Currency Pricing (LCP) could exist, where the pass-through used to be zero in the short-run.

Since the demise of the Soviet-type communist regimes at the start of the 1990s, the New Member States (NMSs) of the European Union have made substantial progress in transforming their economies. As a consequence, for a large majority of theses countries, the perspective of EU membership became a reality on May 2004 (the Czech Republic, Poland, Hungary, Slovenia, Slovakia, Latvia, Estonia, Lithuania, Malta and Cyprus) and January 2007 (Romania and Bulgaria), and even some of them have recently adopted the Euro as currency (Slovenia, Malta and Cyprus). There are many economic policy issues such as pricing strategies of foreign exporting firms and the persistence of inflation. Also, the impact of entering into a monetary union could influence the rate of ERPT to prices and its evolution in different time horizons and sectors. All these countries have developed structural reforms and implemented macroeconomic stabilisation programs which give a great diversity in monetary policy frameworks and exchange rate regimes. So, these factors could affect the size of ERPT of foreign to domestic prices which make it important to study these economies. Likewise, these countries have to pass an inflation criterion set out by the Maastricht Treaty as well as their inflation performances which could be influenced by the ERPT. Once they belong to the Euro Area we should not forget about the effect of different rates of ERPT which could contribute to national inflation differentials.

In this paper I study the ERPT of foreign to domestic prices using data on import unit values (IUVs) for nine different product categories in some NMSs of the European Union (Cyprus, Hungary, Latvia, Poland, the Czech Republic, Slovakia, Slovenia and Romania) and one candidate country (Turkey) from 2000 to 2006 using monthly data. The contribution of this paper is 
threefold. First, it is the first paper in the empirical literature to study ERPT that originate inside the euro area taking into consideration a division by categories of import products ${ }^{1}$. The second goal of the paper is to compare how robust the results derived are through the application of the two different methodological approaches and study the transmission through the pricing chain. The first one is based on Campa and González-Mínguez (2006) which estimates the short- and long-run pass through elasticities, where longrun elasticities are defined as the sum of the pass-through coefficients for the contemporaneous exchange rate and its first four lags. The second one is employed by de Bandt, Banerjee and Kozluk (2007) which suggests a longrun Engle and Granger (1987) cointegrating relationship and the possibility of structural breaks to restore the long-run in the estimation. Finally, the third goal of the paper is to study the transmission through the pricing chain.

Some recent theoretical and empirical studies have analysed the ERPT of foreign to domestic prices beyond the debate over the one price law and convergence across countries. From a theoretical point of view, the debate has been initiated over optimal monetary policy and exchange regimes ${ }^{2}$. This also started the issues and concerns regarding the prevalence PCP versus LCP hypothesis of imports and on whether pass-through rates are endogenous to the inflation performance of a country (Taylor, 2001; Devereux and Engel, 2001 and Bacchetta and van Wincoop, 2001).

The majority of empirical studies (see, for instance, Campa and GonzalezMinguez, 2006; Campa, Goldberg and Gonzalez-Minguez, 2005; Frankel, Parsley and Wei, 2005; Marazzi et al., 2005) over the last twenty years have been focusing on the United States and countries inside of the euro area, in response to changes in institutional arrangements (such as the arrival of the euro currency) and shocks by the monetary system (ERM crisis in 1992) ${ }^{3}$. More recently, de Bandt et al. (2007) not only discuss the issues of estimating short- and long-run exchange rate pass-through but also to review some problems with measures recently proposed in economic literature by the previous studies. These authors consider that techniques used to estimate

\footnotetext{
${ }^{1}$ Ca'Zorzi, Hahn and Sánchez (2007) examine the degree of exchange rate pass-through in emerging markets in Central and Eastern Europe such as Hungary, Poland, the Czech Republic and Turkey in its sample. Darvas (2001) and Coricell et al. (2003) cover in their studies exchange rate pass-thorugh issue indirectly.

${ }^{2}$ See Corsetti and Pesenti (2001, 2005), Obtsfeld (2002), Devereux (2000), Devereux and Engel (2002) and Devereux, Engel and Tille (2003).

${ }^{3}$ Menon (1995) reviews 43 empirical papers about exchange rate pass-through and indicates that most of the heterogeneity in the results is driven by different estimation techniques and different data coverage.
} 
import or export exchange rate pass-through equations were inappropriate and point out that a proper determination of the short run ERPT relied on appropriate assumption on the long run.

A number of empirical Studies mentioned above have explored changes in the exchange rate pass-through and cross-sectional differences at the level of developing economies, the euro area and US. Campa, Goldberg and GonzalezMinguez (2005) investigated changes in the pass-through to import prices in euro area member countries based on data going up to 2004. They detected declines in the size of ERPT on import prices in around two thirds of the industries in their sample, although most of this evidence was not statistically significant. Nevertheless, they found statistically significant effects in manufacturing industries. Sekine (2006) obtained evidence of changes in the ERPT over time on both imports and consumer prices for several developed economies, including Germany, France, Italy, UK, Japan and US. Olivei (2002) and Marazzi et al. (2005) suggested declines in the ERPT on US import prices. Otani et al. (2006) confirmed evidence of a decline in the ERPT to Japanese import prices. Moreover, Bussiere and Peltonen (2007) reported a reduction in the ERPT to import prices in the US and other advanced economies. In contrast to these studies, de Bandt, Banerjee and Kozluk (2007) found evidence of the opposite sign in the changes of the pass-through in some euro area countries like Italy, Portugal and Spain and Thomas and Marquez (2006) derived less evidence of a change in the ERPT to US import prices.

Several complementary explanations have tried to account for the decline in the ERPT and cross-country differences over time. Among the main ones there are macro factors, suggested by Taylor (2001) who links the decline in the ERPT to the decline in inflation that has been observed over the past decades in many countries. According to his argument, lower inflation goes hand in hand with lower persistence of inflation and if cost changes are perceived to be less persistent the pass-through of these shocks will be lower as well. So, a lower persistence of exchange rate shocks could have contributed to the fall of ERPT. This lower inflation environment is likely to be a result of changes in monetary policy (inflation targeting adoption) and these changes could have contributed to the decline in the ERPT by ensuring a lower price increase and by making sure that exchange rate fluctuations do not endanger price stability. Another important macro factor is the nature of the facto exchange rate regime. Some authors justify that a more stable exchange rate regime is indeed likely to induce more LCP and a pass-through decrease for import prices. 
Further potential reasons for the decline in the ERPT could be microeconomic factors, such as shifts in the composition of the import bundle from high pass-through goods such as energy and raw materials to lower pass-through items such as manufactured goods (see Campa and Goldberg, 2005), an increasing in trade integration (see Gust, Leduc and Vigfusson, 2006) or an increasing share of imports denominated in the home currency (see Campa, Golberg and Gonzalez-Minguez, 2005).

My results derive that the hypothesis of LCP (zero pass-through) can be generally rejected for all countries and that the hypothesis of PCP (complete pass-through) is clearly rejected for all the countries except Slovenia and Cyprus by using the Campa and Gonzalez-Minguez (2006) approach. The short-run elasticities are larger for Cyprus, Slovenia and Slovakia and smaller for Latvia, Romania, Turkey and Poland. In the long-run ERPT is slightly lower and again the largest values are in Cyprus and Slovenia and the smallest in Romania, Turkey, Poland and the Czech Republic. Three of these latter countries have adopted inflation targeting in their monetary policies and own a flexible exchange rate system. These results could support evidence in favour of the Taylor's (2001) hypothesis. With reference to the results by industry the lowest values for ERPT are in Basic Manufactures, Chemicals and Manufactured Goods as expected by theory because these type of goods are more differentiated. By applying de Bandt, Banerjee and Kozluz (2007) methodology I derived very similar results to these authors in the sense that some NMSs like Poland could have clearly increased the size of ERPT. By industries there are many divergences and it is not completely clear a ERPT decrease in the Manufacturing sector. I only find clear evidence for some industries in Cyprus, Latvia, Slovenia and Romania. Nevertheless it is easier to find evidence of a ERPT declines in Food $\&$ Live Animals, Beverages and Tobacco, Crude Materials and Mineral Fuels industries.

Finally, I observe the main results to the impact of a $10 \%$ depreciation of the exchange rate of the euro to the cost of intermediation consumption and to final consumption prices. It is also important to keep in mind that divergences in ERPT can also be due to differences in the degree of openness of member countries or differences in the product composition of imports. The highest ERPT to the cost of intermediate consumption is obtained for Hungary, Slovakia and the Czech Republic. In contrast, Cyprus and Slovenia have the lowest. Observing the ERPT to final consumption rates the larger rates are in Hungary and Slovakia. However, I did not find evidence of divergences caused by the degree of openness in the analysis of the cost of intermediation consumption and I find evidence of a decline in the size of ERPT for cost of intermediation and final consumption goods a slight 
divergence caused by the degree of openness by analysing final consumption prices.

This paper is organised as follows: in section 2 I describe and take into account the data used in the empirical analysis and the potential macro and micro factors. In section 3 I present the ERPT equation and the different definitions of short- and long-run exchange rate pass through assumed by the empirical literature mentioned above. In section $4 \mathrm{I}$ offer the main results derived for the different countries under the two approaches. Section 5 I analyse ERPT to the cost of intermediate consumption and final consumption prices. Finally, in section 6 I provide the main conclusions of my analysis. 


\section{Data description and potential macro and micro factors}

In this section, I study the changes in the ERPT using import prices of imports inside the euro zone into the NMSs and Turkey. I use time series data on import unit values for nine different product categories for each country. I focuse my analysis on imports inside the euro area considering that the most important part of the total trade of these countries continually exposed to exchange rate fluctuations. Its size is very important which we will see later. The database that I use in this paper include monthly time series of unit values of imports (IUVs) from euro area countries for nine product categories defined at the one-digit SITC level of aggregation and it is extracted from Eurostat-Comext. As Campa and González-Mínguez (2006) point out, this database has the advantage of focusing explicitly on the product composition of imports into the country and can thus account for different rates of pass-through among different product categories for any given country ${ }^{4}$. As I mentioned in the introduction, accounting for these divergence is important for any meaningful analysis of differences in passthrough rates across and within countries. As differences arise from the product composition of imports exposed to exchange rate fluctuations, we can also account for a significant amount of the aggregate differences of import price pass-through across countries ${ }^{5}$. Data information is offered in Appendix I.

With reference to some potential micro factors determining the ERPT, I could emphasize that the inclusion of these countries as an EU membership could have influenced the shares of different products subject to exchange rate fluctuations. Figure 1 shows, for each country (except Estonia and Turkey) total imports as a percentage of GDP in 2000 and 2006. The majority of them (except Malta) have considerably increased the grade of openness although there is a large divergence among them. The highest value for imports as a percentage of GDP in 2006 is in the Slovakia (83,03\%) and the lowest is in Poland $(36,62 \%)$. Figure 2 illustrates the import of goods from inside the

\footnotetext{
${ }^{4}$ de Bandt et al. (2007) shows a risk of caveat concerning the use of IUV.

${ }^{5}$ Campa and Gonzalez-Mínguez (2006) point out that import price data has several limitations for the analysis of pass-through behavior because it is an index based on unit values rather than prices, which create some problems concerning the comparability of goods over time. This index is not capable of measuring either changes in the quality or for changes in relative demand of similar goods or changes in the composition of imports by country of origin.
} 
euro area in 2000 and 2006. Slovenia is the country with the highest share of imports inside the euro area to GDP, $65.34 \%$, in 2006. At the other end, Lithuania reaches $33,09 \%$ in 2006 . These results indicate the importance of the trade with the euro area for these countries ${ }^{6}$.

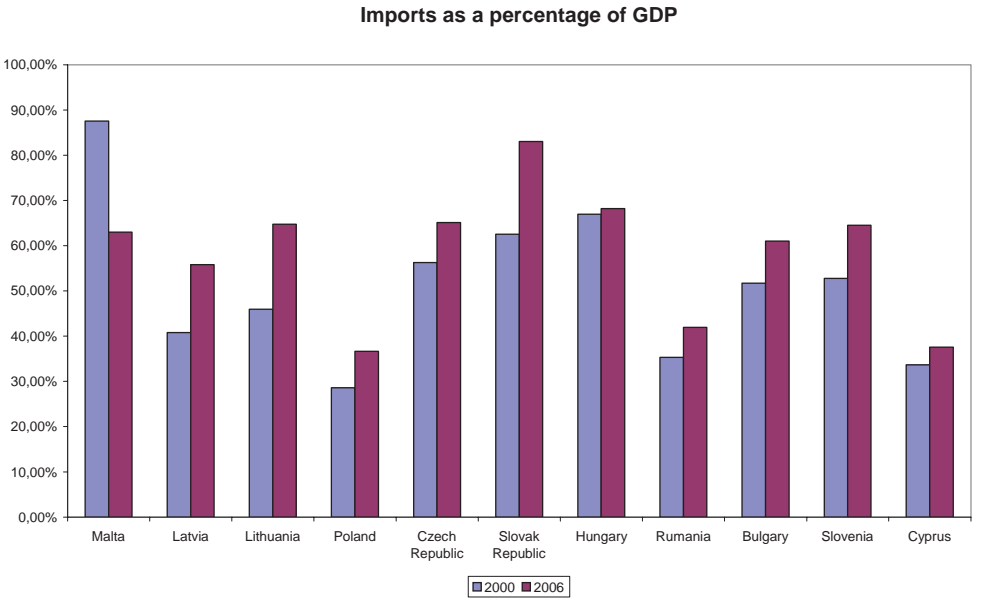

Figure 1: Imports as a percentage of GDP

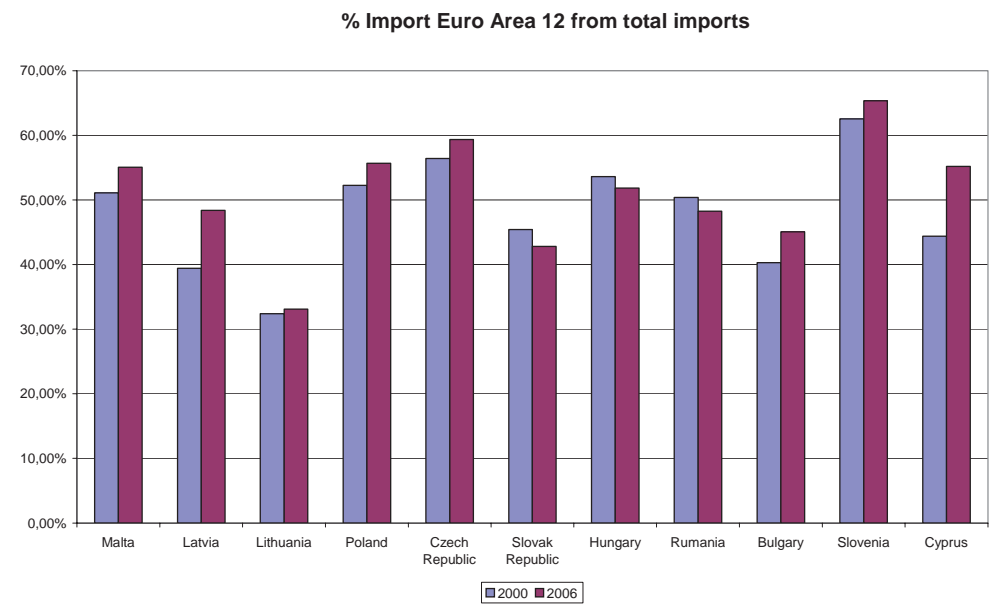

Figure 2: Import Euro Area 12 from total imports

Figure 3 shows the distribution of euro area imports. This distribution also varies widely across different product categories. Vehicles and Transport

\footnotetext{
${ }^{6}$ There are not similar available data for Estonia and Turkey.
} 
Equipment is the most important category $(46,43 \%)$ as a consequence of the outsourcing phenomena in Europe from western to central and eastern countries, followed by Basic Manufactures (17,84\%), Chemicals (11,47\%) and Manufactured Goods (10,81\%). Nevertheless, there is a large degree of heterogeneity. For instance, in Vehicles and Transport Equipment Hungary and Slovakia present the largest values, 56,61\% and 52,49\%, respectively. By contrast, in Slovenia this category is situated around 40\%. Another important example is the Chemical sector where the highest percentage is in Poland $(15,88 \%)$ and the lowest in Malta $(6,42 \%)$. The less important sectors are Beverages and Tobacco and Animal, Vegetable oil \& fat.

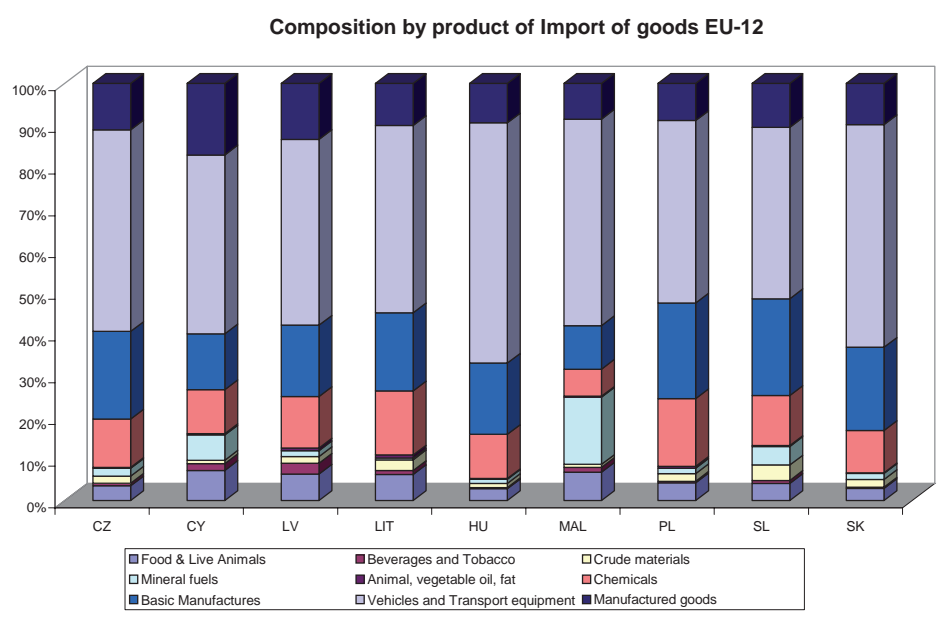

Figure 3: Distribution of euro area imports

In regards to potential macro factors that could have influenced in the size of the ERPT, I proceed to comment the different exchange rate regimes existing in the different countries and the date of adoption of inflation targeting in some countries. The majority of the countries which have adopted an inflation targeting in their monetary policy have a flexible exchange rate. For instance, Hungary had a crawling band exchange rate regime from 1995 to 2000 and changed its regime to a more flexible system (managed float) in 2000. The Czech Republic case is very similar to Hungary. It went from a crawling band system in 1996 to a manage float during the 1997-2000 period and decided to adopt an independent float exchange rate from 2001 to 2002 and then turned back to a managed float in 2003. Poland had a crawling band exchange rate system from 1995 to 1999 and adopted an independent float regime in $2000^{7}$. Cyprus had a fixed pegs system during the 1991-99

\footnotetext{
${ }^{7}$ The dates of adoption of inflation targeting for the Czech Republic, Hungary and
} 
period and adopted an horizontal bands system in 2001. With reference to the Slovakia case a crawling band exchange system was implemented for the 1996-97 period and a managed float regime after 1997. Slovenia was the first country in this group to adopt the Euro (January, 2007) that had previously changed from a flexible exchange rate system (managed float) to a less flexible one (pegged within horizontal bands). Malta has always remained with another conventional fixed peg system to a basket and it has recently accepted the Euro (January, 2008) together with Cyprus. The Latvian case is very similar to Malta and the main objective of its monetary policy is to maintain a fixed parity against a basket of currencies (a conventional fixed pegs). In Estonia, the exchange rate system for the 1992-2006 period was the currency board. Romania has moved from a exchange rate with crawling bands to a managed float in 2004. By contrast, Bulgaria and Lithuania have always remained in a pegged system with horizontal bands. Finally, among the countries candidates group, Turkey owns an explicit inflation targeting from May 2001 and an independent floating exchange rate.Table 1 shows the different exchange rate regimes for the NMS and Turkey from 2000 to 2006.

Table 1: Exchange rate regimes in the new member states of the EU and candidate countries

\begin{tabular}{|l|l|l|l|l|l|l|l|}
\hline & 2000 & 2001 & 2002 & 2003 & 2004 & 2005 & 2006 \\
\hline Bulgaria & 2 & 2 & 2 & 2 & 2 & 2 & 2 \\
\hline Czech Republic & 7 & 8 & 8 & 7 & 7 & 7 & 7 \\
\hline Cyprus & 3 & 4 & 4 & 4 & 4 & 4 & 4 \\
\hline Hungary & 6 & 7 & 7 & 4 & 4 & 4 & 4 \\
\hline Estonia & 2 & 2 & 2 & 2 & 2 & 2 & 2 \\
\hline Latvia & 3 & 3 & 3 & 3 & 3 & 3 & 3 \\
\hline Lithuania & 2 & 2 & 2 & 2 & 2 & 2 & 2 \\
\hline Malta & 3 & 3 & 3 & 3 & 3 & 3 & 3 \\
\hline Poland & 8 & 8 & 8 & 8 & 8 & 8 & 8 \\
\hline Romania & 6 & 6 & 6 & 6 & 7 & 7 & 7 \\
\hline Slovak Republic & 7 & 7 & 7 & 7 & 7 & 4 & 4 \\
\hline Slovenia & 7 & 7 & 7 & 6 & 4 & 4 & 4 \\
\hline Turkey & 8 & 8 & 8 & 8 & 8 & 8 & 8 \\
\hline
\end{tabular}

1. ER arrangements with no separate legal tender; 2. Currency board; 3. Other conventional fixed pegs; 4. Pegged within horizontal bands; 5. Crawling pegs; 6 . Exchange rate with crawling bands; 7 . Managed floating; 8. Independent floating.Source: IMF

Poland are January 1998, June 2001 and October 1998, respectively. 
In order to analyse the ERPT, there are two essential parts of the analysis: the nominal exchange rates and the marginal cost, as well as foreign price and proxy. To establish an accurate definition of these variable, I take into account the relevant international market for the product. If there is possible integration in the world market, there exists only a single international market for the product, regardless of product origin, destination market or currency denomination. In this case, measuring the world price should be the same when expressed in a common currency. I use the world price in a common currency to stablish an appropriate measure of the foreign price and the exchange rate and I also include the bilateral exchange rate between the currency in which the foreign prices is denominated and the home currency. When studying this case, the world price will be expressed in euros and we will use, for a given product, the euro price of imports coming from euro area. As well as our proxy for the foreign price and bilateral exchange rate between the domestic currency and the euro as our exchange rate measure. This hypothesis is not preposterous if we look at the Figure 2 where there is a huge amount of imports proceeding from the euro area in these countries ${ }^{8}$.

\section{Estimation of Exchange Rate Pass-Through into Import Prices: the two alternatives}

By definition import prices for any type of goods $\mathrm{j}, M P_{t}^{j}$ are a transformation of export prices of a country's trading partners $X P_{t}^{j}$ using the bilateral exchange rate $E R_{t}{ }^{9}$. So, we have:

$$
M P_{t}^{j}=E R_{t} * X P_{t}^{j}
$$

Taking logs we obtain:

$$
m p_{t}^{j}=e r_{t}+x p_{t}^{j}
$$

where the export price consists of the exporters marginal cost and a markup:

$$
X P_{t}^{j}=F M C_{t}^{j} * F M K U P_{t}^{j}
$$

\footnotetext{
${ }^{8}$ Campa and González-Mínguez (2006) perfomed $\mathrm{J}_{A}$-tests to determine which specification of market structure (integrated or segmented) for the euro area countries originating outside the area is more appropiate and they obtain that the best option is the one integrated.

${ }^{9} \mathrm{I}$ base this section on Campa, Goldberg and Gonzalez-Minguez (2005) and de Bandt, Banerjee and Kozluk (2007).
} 
So, we obtain:

$$
x p_{t}^{j}=f m c_{t}^{j}+f m k u p_{t}^{j}
$$

Substituting (4) into (2) yields:

$$
m p_{t}^{j}=e r_{t}+f m c_{t}^{j}+f m k u p_{t}^{j}
$$

Expression (5) offer us the three main determinants of the ERPT: (i) effects of the exchange rate movement, (ii) marginal cost effects attributable or not to the exchange rate movements and (iii) markup responses; assuming unity translation of exchange rate movements.

With reference to the markup factor it implicitly depends on the market share of domestic producers relative to foreign producers, the form of competition that exists in the market for the industry and the existence of price discrimination. When a high ERPT is predicted: there is a large share of imports in the total industry supply, a high degree of price discrimination or a larger share of imported inputs in the production in the target country. On the other hand, ERPT could be higher if the ratio of exporters relative to local competitors is high, and lower if the exporters compete for market share and depends on the currency denomination of exports, structure and importance of intermediate goods markets.

Nevertheless, exporters can decide to absorb some of the exchange rate variations instead of passing them through the price in the importing country currency. If the PCP holds the pass-through is complete and markup does not respond to fluctuations of exchange rates. At the other extreme, if LCP holds exporters can decide not to vary prices in the target country currency and assume fluctuations within the markup. So, markup in each industry have two components: (i) a specific industry component and (ii) a reaction to exchange rate movements:

$$
f m k u p_{t}^{j}=\alpha^{j}+\Phi e r_{t}
$$

In regards to the marginal cost, which is a function of demand that conditions in the importing country. it is also important to look at the marginal costs of production (wages) in the exporting country and the commodity prices denominated in foreign currency:

$$
f m c_{t}^{j}=\eta_{0} y_{t}+\eta_{1} f w_{t}+\eta_{2} e r_{t}+\eta_{3} f c p_{t}+\varepsilon_{t}
$$

where $y_{t}$ is the income in the importing country, $f w_{t}$ is the wage and $f c p_{t}$ is the commodity price index in foreign currency. 
substituting (7) and (6) into (5), we derive:

$$
m p_{t}^{j}=\alpha+\underbrace{\left(1+\Phi+\eta_{2}\right)}_{\beta} e r_{t}+\underbrace{\eta_{0} y_{t}+\eta_{1} f w_{t}+\eta_{3} f c p_{t}}_{\gamma f p_{t}}+\varepsilon_{t}
$$

This equation can be written as:

$$
m p_{t}^{j}=\alpha+\beta e r_{t}+\gamma f p_{t}+\varepsilon_{t}
$$

where $\beta$ captures the pass-through elasticity and $\eta_{0} y_{t}+\eta_{1} f w_{t}+\eta_{3} f c p_{t}$ it is consider independent of the exchange rate and is reflected in the world price of the product, $f p_{t}$, in the world currency. Likewise, it also gives us in the long run a connection between the import price, exchange rate and a measure of the foreign price.

\subsection{Campa and González-M inguez (2006) methodology}

Each of these series in equation (9) use to be considered by a unit root although some authors are not able to reject the null hypothesis of the nonexistence of a cointegrating relationship among the three series and proceed by estimating the previous equation in first differences:

$$
\Delta m p_{t}^{j}=a+\sum_{k=0}^{4} b_{k} \Delta e r_{t-k}+\sum_{k=0}^{4} c_{k} \Delta f p_{t-k}+\varepsilon_{t}
$$

for a certain type of good $i$ in a certain country $j$. The coefficient $b_{0}$ offers us the short-run ERPT and they propose the sum of coefficients $\sum_{k=0}^{4} b_{k}$ as the long-run ERPT.

They allow the possibility of partial adjustment of the rule setting import prices with a flexible form and this adjustment path could vary by industry according to the macro and micro factors mentioned above ${ }^{10}$ and they focus on testing LCP (zero pass-through) and PCP (complete pass-through) hypothesis in the short-and long run.

\footnotetext{
${ }^{10}$ Campa and González-Mínguez also estimate the model considering the first lag of the dependent variable as explanatory variable although their main results remain.
} 


\section{2 de Bandt, Banerjee and Kozluk (2007) methodology}

As de Bandt, Banerjee and Kozluk (2007) pointed out, the Campa and González-Mínguez (2007) definition of the long-run pass-through, which is constructed by summing the estimated coefficients for the first five lags is somewhat arbitrary and thus rather inadequate for the purpose of enquiring about the actual long run effect. The election of five lags is something arbitrary and this measure does not take into account the significance of the coefficients on the individual lags.

If the cointegrated equilibrium relationship were to exist, the previous equation would be misspecified and the estimated equation should contain an error correction term (ECM), as in Engle and Granger (1987) and thus would take the following form:

$\Delta m p_{t}^{j}=a+\sum_{k=0}^{K_{1}} b_{k} \Delta e r_{t-k}+\sum_{k=0}^{K_{2}} c_{k} \Delta f p_{t-k}+\lambda\left(m p_{t-1}^{j}-\hat{\alpha}-\hat{\beta} e r_{t-1}-\hat{\gamma} f p_{t-1}\right)+u_{t}$

The estimations provided by Campa and González-Mínguez (2006) could have failed to find a cointegrating relationship in series by an inappropriate lag length selection or proper accounting for a structural break ${ }^{11}$.

\section{Empirical results}

In this section, I offer the main results for the estimated ERPT in some NMSs and Turkey using the two methodological approaches indicated in the previous section. I finally analyse ERPT in the Czech Republic, Poland, Hungary, Latvia, Slovakia, Slovenia, Cyprus, Romania and Turkey. I drop Estonia, Malta, Lithuania and Bulgaria out of the sample because bilateral exchange rate variations were null during the majority of the sample period. Figure 4 illustrates us exchange rate changes in these four countries (20002006).

\footnotetext{
${ }^{11}$ These authors point out that almost all the theories contain a long-run or steadystate relationship in the levels of a measure of import unit values, the exchange rate and a measure of foreign prices and this long run is disregarded in most of the empirical implementations.
} 

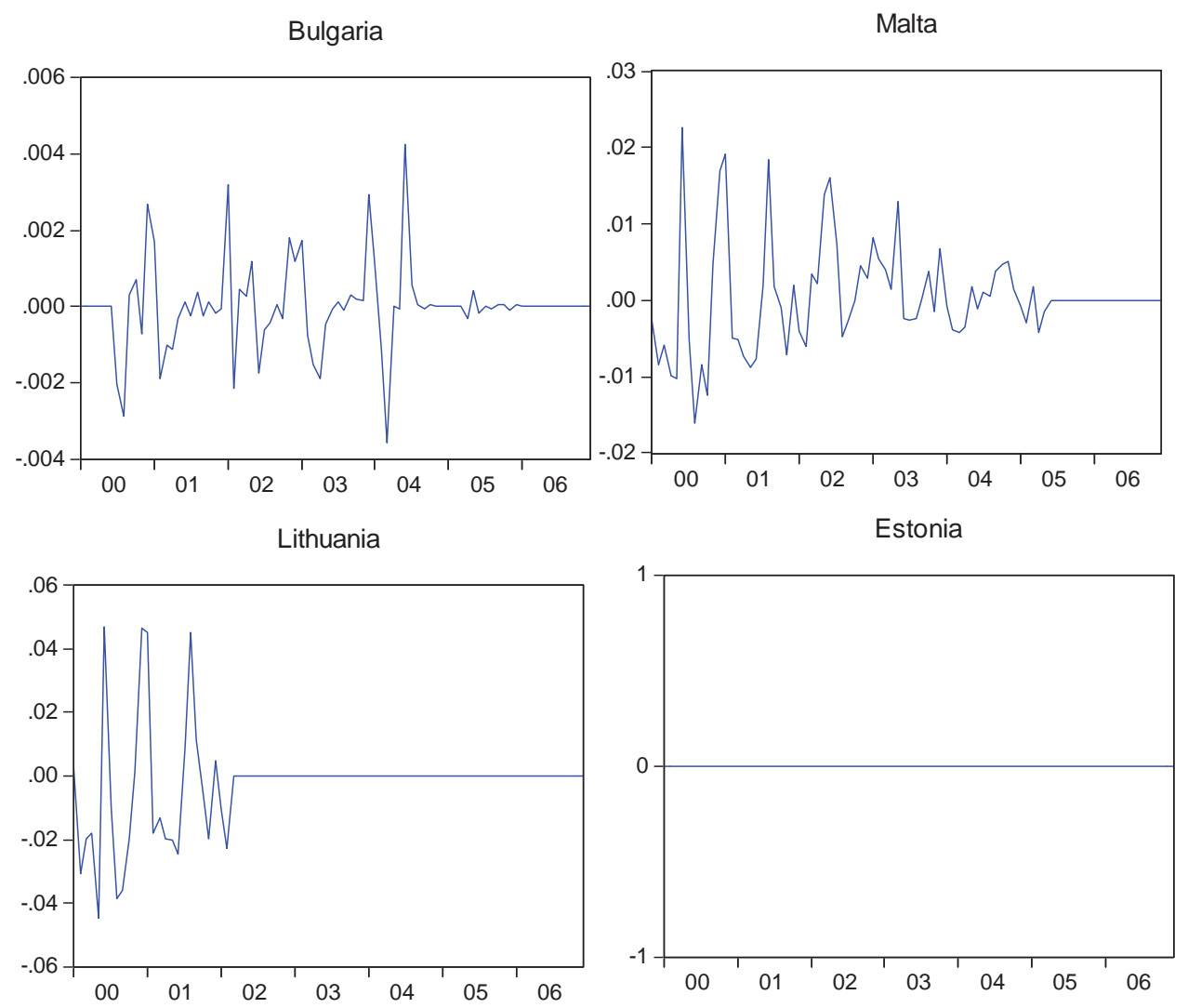

Figure 4: Exchange rate variations in some NMSs countries

\subsection{A preliminary step: cointegration analysis}

There are a number of reasons why we expect there might be a change in the long run ERPT within our sample period. For instance, on May, 2004, ten NMSs entered into the EU. This supposed important changes in these economies. I can use as an example the Slovenian case. On the left hand of Figure 5 we have the residuals from the estimation of equation (9) for the SITC_0 industry (Food and live animals) without a break and on the right hand the residuals with a break on May, 2004. As we can see residuals with a break become more stationary. We will obtain similar results using another series in our sample. The important lesson that we learn here is that forgetting about structural breaks may lead us to the failure of finding a long run relationship. 

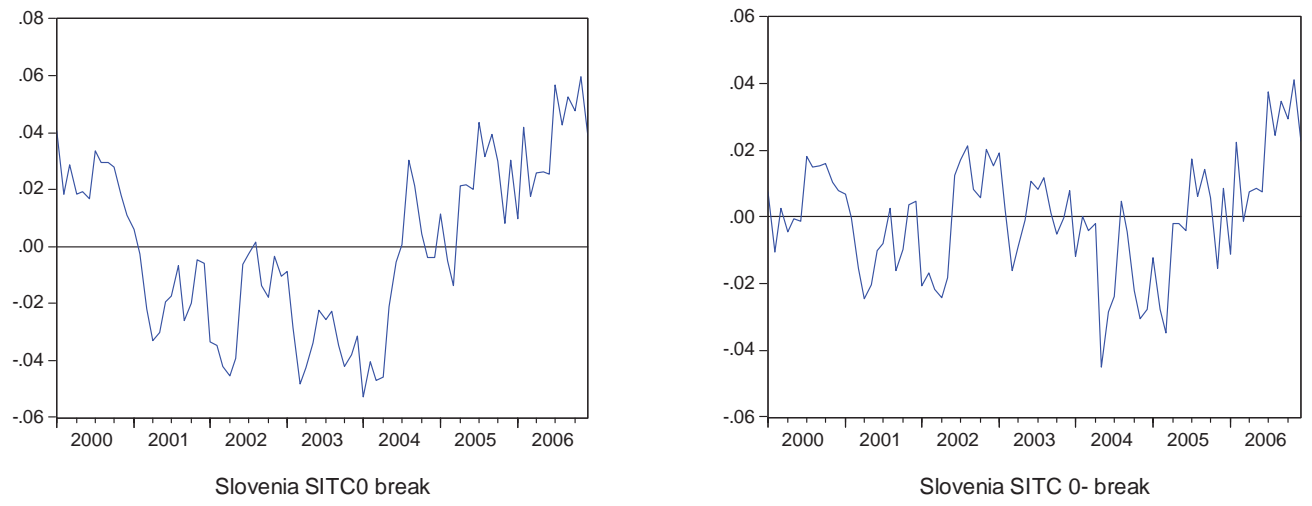

Figure 5: Residuals from the estimation of (9) without a break and with a single break for Slovenia, SIT0.

If we do simple ADF tests for cointegration in time series for individual country/industry combinations we obtain a rejection of the null of no cointegration for over $11 \%$ of the series (at $5 \%$ level). Then, there is a evidence that in the long run, the relationship levels, in the Engle and Granger (1987) sense exists between these variables. Table 2 show the ADF tests in single time series for individual country/industry combinations. 
Table 2: ADF tests in single time series for individual country/industry combinations

\begin{tabular}{|c|c|c|c|c|c|c|c|c|c|}
\hline Country & SITC0 & SITC1 & SITC2 & SITC3 & SITC4 & SITC5 & SITC6 & SITC7 & SITC8 \\
\hline $\mathrm{CZ}$ & $-5.96^{* * *}$ & $-3.77^{* * *}$ & $-4.13^{* * *}$ & -2.24 & $-3.48^{* * *}$ & $-3.90^{* * *}$ & -1.80 & $-4.23^{* * *}$ & -2.48 \\
\hline PL & $-4.33^{* * *}$ & $-5.48^{* * *}$ & $-4.35^{* * *}$ & $-2.99^{* * *}$ & $-3.63^{* * *}$ & $-5.43^{* * *}$ & $-4.51^{* * *}$ & $-5.46^{* * *}$ & $-7.55^{* *}$ \\
\hline HU & $-3.38^{* * *}$ & $-5.73^{* * *}$ & -2.22 & $-4.06^{* * *}$ & $-4.66^{* * *}$ & $-4.70^{* * *}$ & $-7.54^{* * *}$ & $-4.33^{* * *}$ & $-5.55^{* * *}$ \\
\hline SL & $-3.08^{* * *}$ & $-4.24^{* * *}$ & -2.33 & $-4.44^{* * *}$ & $-3.15^{* * *}$ & $-5.52^{* * *}$ & -2.30 & $-4.49^{* * *}$ & -2.80 \\
\hline $\mathbf{L V}$ & $-3.83^{* * *}$ & $-5.99^{* * *}$ & $-6.42^{* * *}$ & $-6.54^{* * *}$ & - & $-6.82^{* * *}$ & $-5.97^{* * *}$ & $-6.67^{* * *}$ & $-5.71^{* * *}$ \\
\hline $\mathbf{C Y}$ & $-7.47^{* * *}$ & $-7.69^{* * *}$ & $-5.37^{* * *}$ & - & - & $-9.03^{* * *}$ & $-5.15^{* * *}$ & $-4.29^{* * *}$ & $-9.02^{* * *}$ \\
\hline SK & $-5.30^{* * *}$ & $-5.40^{* * *}$ & $-3.96^{* * *}$ & $-3.94^{* * *}$ & $-6.58^{* * *}$ & $-2.87^{* *}$ & $-2.79^{*}$ & $-5.13^{* * *}$ & $-4.68^{* * *}$ \\
\hline $\mathbf{R U}$ & $-4.09^{* *}$ & $-5.07^{* * *}$ & $-5.46^{* * *}$ & $-6.40^{* * *}$ & $-9.37^{* * *}$ & $-6.01^{* * *}$ & $-3.36^{* * *}$ & $-6.66^{* * *}$ & $-3.82^{* * *}$ \\
\hline TK & -1.88 & $-4.86^{* * *}$ & $-4.42^{* * *}$ & $-6.20^{* * *}$ & $-4.93^{* * *}$ & $-3.93^{* * *}$ & $-.3 .64^{* * *}$ & $-4.95^{* * *}$ & $-4.41^{* * *}$ \\
\hline
\end{tabular}

I report the ADF t-statistic and ${ }^{*},{ }^{* *}$ and ${ }^{* * *}$ indicate whether the hypothesis of

unit root cannot be rejected at $10 \%, 5 \%$ and $1 \%$ level.

CZ Czech Republic, CY Cyprus, LV latvia,

HU Hungary,PL Poland,SK Slovakia,

$\mathrm{RU} \sim$ Romania,TK Turkey,SL $\sim$ Slovenia 


\subsection{A first approximation: applying Campa and Gonzalez- Minguez Methodology (2006)}

In spite of the previous result, a good approximation is to estimate equation (10) by ordinary least squares (OLS) and estimate the short- and long-run pass-through elasticities for the different countries and industries using a dummy for NMSs countries which contemplates different structural breaks in time series. Then, we define long-run elasticities as the sum of the passthrough coefficients for the contemporaneous exchange rate and its first four lags following Campa and González-Mínguez (2006).

In order to determine dates of structural breaks I use two alternative versions of equation (9): (i) a break in the constant and (ii) a break in all the cointegrating equation coefficients.

$$
\begin{gathered}
m p_{t}^{j}=\hat{\alpha}+\hat{\alpha}_{1} d_{s}+\hat{\beta} e r_{t}+\hat{\gamma} f p_{t}+\varepsilon_{t} \\
m p_{t}^{j}=\hat{\alpha}+\hat{\alpha}_{1} d_{s}+\hat{\beta} e r_{t}+\hat{\beta}_{1} e r_{t} d_{s}+\hat{\gamma} f p_{t}+\hat{\gamma}_{1} f p_{t} d_{s}+v_{t}
\end{gathered}
$$

where $d_{s}$ is a dummy variable equal to 0 if $\mathrm{t}<\mathrm{s}$ and equal to 1 otherwise. I use the Quandt-Andrews unknown breakpoint test to derive dates for breaks in both types of specification. I should expect the coefficient of the markup, $\hat{\alpha}$, to decrease due to the integration of these countries inside the EU or an increase in the expectations of belonging in the near future. Table 3 indicates that in the specification of break only in a constant the fixed component in the mark-up tend to rise more than decrease (23 out 76 significant series are negative, 30\%). Nevertheless, the specification in (11) is much more restrictive than the one based in (12). In this case for 8 out 32 of the significant series are negative $(25 \%)^{12}$.

I also did a ADF test for individual country/industry combinations considering both specifications and I find that the rejection of the null of no cointegration only was possible for 1 out 78 series in the two versions of the model. Table 3 offers us estimated directions, significances and dates for breaks. I show the specification of breaks in the entire cointegrating vector and whether the change is positive or negative and its significance.

\footnotetext{
${ }^{12}$ The specification from equation (11) is much more restrictive than the one based on equation (12), not allowing for a possible break in the other variables and causing the estimate of $\alpha_{1}$ to be biased.
} 
Table 3: Directions, significance and dates for breaks.

\begin{tabular}{|c|c|c|c|c|c|c|c|c|c|c|c|c|c|c|c|c|c|c|}
\hline \multirow[b]{2}{*}{ Industry } & \multicolumn{2}{|c|}{$\mathrm{CZ}$} & \multicolumn{2}{|c|}{ LV } & \multicolumn{2}{|c|}{$\mathrm{CY}$} & \multicolumn{2}{|c|}{ PL } & \multicolumn{2}{|c|}{$\mathrm{HU}$} & \multicolumn{2}{|c|}{ SL } & \multicolumn{2}{|c|}{ SK } & \multicolumn{2}{|c|}{$\mathrm{RU}$} & \multicolumn{2}{|c|}{ TK } \\
\hline & (1) & (2) & (1) & (2) & (1) & (2) & (1) & (2) & (1) & (2) & (1) & (2) & (1) & (2) & (1) & (2) & (1) & (2) \\
\hline & $1 / 03$ & $1 / 02$ & $7 / 04$ & $9 / 02$ & & 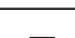 & $9 / 05$ & $6 / 03$ & $5 / 01$ & 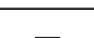 & $6 / 04$ & $5 / 04$ & $5 / 04$ & $11 / 02$ & $9 / 05$ & 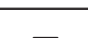 & $5 / 04$ & $5 / 04$ \\
\hline $\mathrm{SITC}_{-}{ }^{0}$ & $*,-$ & $*,-$ & $*,-$ & ${ }^{*},+$ & - & - & $*,+$ & $*,-$ & $*,+$ & - & $*,+$ & $*,-$ & $*,+$ & $*,+$ & $*,+$ & - & ${ }^{*},+$ & + \\
\hline SITC_ 1 & $\begin{array}{l}6 / 04 \\
*\end{array}$ & - & $\begin{array}{c}4 / 01 \\
*+\end{array}$ & - & $\begin{array}{c}2 / 03 \\
*\end{array}$ & - & $\begin{array}{l}1 / 02 \\
*\end{array}$ & - & $\begin{array}{l}7 / 05 \\
*,+\end{array}$ & $\begin{array}{c}7 / 05 \\
-\end{array}$ & $4 / 05$ & $\begin{array}{l}5 / 05 \\
*\end{array}$ & 1/02 & $4 \longdiv { 0 4 }$ & $1 / 04$ & $\begin{array}{c}1 / 04 \\
+\end{array}$ & $\begin{array}{l}5 / 02 \\
*\end{array}$ & $\begin{array}{c}5 / 02 \\
-\end{array}$ \\
\hline & $5 \longdiv { 0 5 }$ & $5 / 05$ & $12 / 04$ & $12 / 05$ & $3 / 01$ & $4 / 06$ & $5 / 01$ & $5 / 01$ & $2 / 01$ & $5 / 01$ & $5 / 04$ & $6 / 04$ & $9 / 01$ & $1 / 02$ & $5 / 01$ & $3 / 01$ & $7 / 02$ & $3 / 06$ \\
\hline SITC $_{-} 2$ & $*,-$ & $*,-$ & $*,+$ & $*,+$ & $*,+$ & - & $*,+$ & - & + & $*,+$ & $*,-$ & $*,-$ & $*,+$ & $*$ & $*,+$ & + & $*,-$ & + \\
\hline $\mathrm{SITC}_{-} 3$ & $\begin{array}{l}/ 04 \\
*,+\end{array}$ & $\begin{array}{l}4 / 04 \\
*,-\end{array}$ & $\begin{array}{c}11 / 05 \\
*,-\end{array}$ & - & $\begin{array}{l}5 / 05 \\
*,+\end{array}$ & $\begin{array}{c}5 / 05 \\
-\end{array}$ & $\begin{array}{l}4 / 04 \\
*,+\end{array}$ & $\begin{array}{l}3 / 04 \\
*,+\end{array}$ & $\begin{array}{l}1 / 02 \\
*,-\end{array}$ & $\begin{array}{l}1 / 02 \\
*++\end{array}$ & $9 \longdiv { 0 1 }$ & $\begin{array}{c}11 / 01 \\
*,+\end{array}$ & $\begin{array}{l}11 / 05 \\
* .-\end{array}$ & $3 / 01$ & $\begin{array}{l}10 / 04 \\
*\end{array}$ & $\begin{array}{c}10 / 04 \\
+\end{array}$ & - & - \\
\hline $\mathrm{SITC}_{-} 4$ & $\begin{array}{l}5 / 05 \\
*,-\end{array}$ & $\begin{array}{c}1 / 05 \\
+\end{array}$ & - & - & - & - & $\begin{array}{c}10 / 02 \\
*,+\end{array}$ & $\begin{array}{c}2 / 06 \\
+\end{array}$ & $\begin{array}{c}12 / 03 \\
-\end{array}$ & $\begin{array}{c}12 / 03 \\
+\quad\end{array}$ & $\begin{array}{l}8 / 05 \\
*,-\end{array}$ & $\begin{array}{c}11 / 04 \\
*,-\end{array}$ & $\begin{array}{l}4 / 01 \\
*,+\end{array}$ & $\begin{array}{l}8 / 05 \\
*,+\end{array}$ & 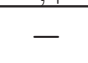 & - & $\begin{array}{l}9 / 03 \\
*,+\end{array}$ & $\begin{array}{c}/ 06 \\
*,-\end{array}$ \\
\hline SITC_ $_{-} 5$ & $\begin{array}{c}10 / 04 \\
*\end{array}$ & $10 / 04$ & - & - & - & - & $10 / 04$ & $6 / 03$ & $\begin{array}{l}2 / 01 \\
*\end{array}$ & $\begin{array}{l}/ 01 \\
*\end{array}$ & $\begin{array}{l}9 / 01 \\
*\end{array}$ & $2 / 01$ & $3 / 01$ & $3 / 01$ & $10 / 04$ & $10 / 04$ & $5 / 03$ & $5 \longdiv { 0 3 }$ \\
\hline & $9 / 04$ & $6 / 03$ & $1 / 02$ & $1 / 02$ & $6 / 05$ & $9 / 04$ & $\frac{+}{10 / 01}$ & $4 / 06$ & $10 / 04$ & $10 / 04$ & $6 / 04$ & $\stackrel{,+}{12 / 01}$ & $8 \longdiv { - 0 4 }$ & $8 / 04$ & $9 / 04$ & $3 / 06$ & $4 / 04$ & $\frac{+}{4 / 04}$ \\
\hline SITC $_{-} 6$ & $*,+$ & $*,-$ & $*,-$ & $*,+$ & $*,-$ & $*,+$ & $*,+$ & $*,+$ & $*,+$ & + & $*,-$ & $*,+$ & $*,+$ & + & $*,+$ & $*,+$ & $*,+$ & $*,+$ \\
\hline SITC 7 & $8 / 03$ & $8 / 03$ & $12 / 04$ & - & $5 / 04$ & - & $9 / 04$ & $9 / 04$ & $6 / 03$ & $8 / 01$ & $9 / 05$ & $4 / 05$ & $1 / 04$ & $1 / 05$ & - & - & $2 / 03$ & $6 / 01$ \\
\hline $511 C_{-}$ & $*,+$ & - & ${ }^{*},+$ & - & ${ }^{*},-$ & - & $*,+$ & + & + & $*,-$ & ${ }^{*},+$ & $*,-$ & ${ }^{*},+$ & 10 & - & 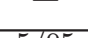 & ${ }^{*},-$ & ${ }^{*},+$ \\
\hline SITC_8 $_{-}$ & $\begin{array}{l}9 / 03 \\
*,+\end{array}$ & $\begin{array}{c}10 / 03 \\
-\end{array}$ & $\begin{array}{c}7 / 05^{*} \\
*,+\end{array}$ & - & $\begin{array}{l}5 / 02 \\
*,+\end{array}$ & - & $\begin{array}{l}3 / 04 \\
*,+\end{array}$ & - & - & $\begin{array}{c}5 / 01 \\
-\end{array}$ & $\begin{array}{l}5 / 04 \\
*,+\end{array}$ & $\begin{array}{l}5 / 04 \\
*,+\end{array}$ & $\begin{array}{l}5 / 05 \\
*,+\end{array}$ & $\begin{array}{c}4 / 03 \\
+\end{array}$ & $\begin{array}{l}/ 05 \\
*,+\end{array}$ & $\begin{array}{c}5 / 05 \\
-\end{array}$ & $\begin{array}{c}11 / 01 \\
*,-\end{array}$ & - \\
\hline
\end{tabular}

(1) represents the specification of break in constant and (2) the specification of break in the entire cointegrating vector and ${ }^{*}$ indicate whether it is significant at $5 \%$. 
Once I have derived the different structural breaks in our time series I estimate equation (10) by OLS. In some industries, I include a correction for first-order autocorrelation because there are many residual autocorrelation. These estimated elasticities are included in Appendix II. Table 4 reports the estimated short- and long-run elasticities with the restriction that ERPT is the same for all industries within a given country. Table 5 reports a summary statistics of these estimated short- and long-run ERPT for the different industries within a country. As we can see ERPT is incomplete in the short-run for all the countries except Cyprus (where the elasticity is greater than one), Latvia (next to one) and Slovenia (equal to one). The hypothesis of LCP (zero pass-through) cannot be rejected for all the countries and the hypothesis of PCP (complete pass-through) is clearly rejected for all the countries but Slovenia and Cyprus. The short-run elasticities are larger for Cyprus, Slovenia and Latvia and smaller for Turkey, Romania, Poland, the Czech Republic and Hungary. In the long-run ERPT is slightly smaller and again the largest values are in Cyprus, Latvia and Slovenia and the smallest in Turkey, Romania, Poland and the Czech Republic. 
Table 4. Differences in ERPT rates by country

\begin{tabular}{|l|l|l|}
\hline Country & S/R PT & L/R PT \\
\hline Czech Republic & $0.2363^{\dagger}$ & $0.3104^{\dagger}$ \\
\hline Cyprus & 2.916 & 2.242 \\
\hline Latvia & $0.909^{\dagger}$ & $0.756^{\dagger}$ \\
\hline Hungary & 0.324 & $0.487^{\dagger}$ \\
\hline Poland & $0.252^{\dagger}$ & $0.257^{\dagger}$ \\
\hline Slovak Republic & $0.503^{\dagger}$ & 0.362 \\
\hline Romania & $0.197^{\dagger}$ & $0.382^{\dagger}$ \\
\hline Turkey & $0.090^{\dagger}$ & $0.102^{\dagger}$ \\
\hline Slovenia & 1.00 & 0.760 \\
\hline Average & $\mathbf{0 . 7 1 4}$ & $\mathbf{0 . 6 3 1}$ \\
\hline
\end{tabular}

Source: Eurostat and own calculations. ${ }^{* \dagger}$ It can be statistically rejected that the pass-through is zero/one

S/R PT Short-run pass-through \& L/R PT Long-run pass-through

Table 5. Percentage of total industries for which the tested hypothesis can be rejected

\begin{tabular}{|c|c|c|c|c|}
\hline Country & $\mathbf{S} / \mathbf{R}$ & $\mathbf{S} / \mathbf{R}$ & $\mathbf{L} / \mathbf{R}$ & $\mathbf{L} / \mathbf{R}$ \\
\hline & $\mathbf{P T}=\mathbf{0}$ & $\overline{\mathrm{PT}}=1$ & $\mathrm{PT}=\mathbf{0}$ & $\overline{\mathrm{PT}}=1$ \\
\hline Czech Republic & 0.0 & 77.77 & 0.0 & 55.55 \\
\hline Cyprus & 0.0 & 0.0 & 0.0 & 0.0 \\
\hline Latvia & 12.5 & 50.0 & 0.0 & 50.0 \\
\hline Hungary & 11.11 & 44.44 & 22.22 & 77.77 \\
\hline Poland & 22.22 & 66.66 & 33.33 & 55.55 \\
\hline Slovak Republic & 44.44 & 77.77 & 0.0 & 44.44 \\
\hline Romania & 22.22 & 77.77 & 0.0 & 77.77 \\
\hline Turkey & 11.11 & 22.22 & 0.0 & 100.0 \\
\hline Slovenia & 11.11 & 22.22 & 0.0 & 33.33 \\
\hline
\end{tabular}

How can we interpret these results?. First, three of the countries with the smallest pass-through, the Czech Republic, Poland and Turkey have adopted inflation targeting in their monetary policies and owns a flexible exchange rate system. This gives evidence and supports Taylor's (2001) hypothesis. Second, we expect a positive relationship between openness and the estimated long-run ERPT. This result is derived for Slovenia and Hungary but 
not Cyprus where we should expect a smaller long-run ERPT. Third, if we examine the industry composition in Cyprus we can see how the Mineral Fuels industry is essential in relation to other countries $(5,95 \%)$. The importance of the Mineral Fuels industry can explain the anomalous result derived in this country.

With reference to the results by industry Tables 6 and 7 offer the elasticities by type of products. I estimate the ERPT by imposing the restriction that they are equal for a given industry across the nine countries in the sample. Elasticities vary from 0.170 for Basic Manufactures to 0.558 to Animal, vegetable oil and fat in the short-run. In this case, ERPT tend to be more complete in the long-run in some industries like Mineral fuels, and Food and Live Animals. According to the theory, we can see how elasticities are lower in Basic Manufactures, Chemicals and Manufactured Goods.

Table 6. Differences in ERPT rates by industry

\begin{tabular}{|l|l|l|}
\hline Industry & S/R PT & L/R PT \\
\hline 0. Food and live animals & $0.248^{\dagger}$ & 0.883 \\
\hline 1. Beverages and Tobacco & $0.270^{\dagger}$ & $0.403^{\dagger}$ \\
\hline 2. Crude materials & $0.217^{\dagger}$ & $0.216^{\dagger}$ \\
\hline 3. Mineral fuels & $0.464^{*, \dagger}$ & 1.571 \\
\hline 4. Animal, vegetable oil and fat & $0.558^{*, \dagger}$ & 0.570 \\
\hline 5. Chemicals & 0.235 & 0.331 \\
\hline 6. Basic Manufactures & $0.170^{\dagger}$ & $0.128^{\dagger}$ \\
\hline 7. Vehicles and transport equipment & $0.274^{\dagger}$ & $0.319^{\dagger}$ \\
\hline 8. Manufactured goods & $0.237^{\dagger}$ & $0.322^{\dagger}$ \\
\hline & & \\
\hline Average & $\mathbf{0 . 2 9 7}$ & $\mathbf{0 . 5 2 7}$ \\
\hline
\end{tabular}

Source: Eurostat and own calculations. ${ }^{*, \dagger}$ It can be statistically rejected that the pass-through is zero/one

S/R PT Short-run pass-through \& L/R PT Long-run pass-through 
Table 7. Percentage of total countries for which the tested hypothesis can be rejected

\begin{tabular}{|l|l|l|l|l|}
\hline Industry & $\mathbf{S} / \mathbf{R}$ & $\mathbf{S} / \mathbf{R}$ & $\mathbf{L} / \mathbf{R}$ & $\mathbf{L} / \mathbf{R}$ \\
\hline & $\mathbf{P T}=\mathbf{0}$ & $\mathbf{P T}=\mathbf{1}$ & $\mathbf{P T}=\mathbf{0}$ & $\mathbf{P T}=\mathbf{1}$ \\
\hline 0. Food \& Live animals & 50 & 100 & 8.33 & 33.33 \\
\hline 1. Beverages \& Tobacco & 25 & 75 & 8.33 & 41.67 \\
\hline 2. Crude Materials & 8.33 & 66.67 & 0 & 58.33 \\
\hline 3. Mineral fuels & 36.36 & 45.45 & 9.09 & 27.27 \\
\hline 4. Animal, vegetable oil \& fat & 37.5 & 87.50 & 12.50 & 25 \\
\hline 5.Chemicals & 9.09 & 54.54 & 0.0 & 54.54 \\
\hline 6. Basic manufactures & 25 & 83.33 & 0.0 & 75.0 \\
\hline 7. Vehicles \& transport equipment & 16.67 & 83.33 & 0.0 & 58.33 \\
\hline 8. Manufactured goods & 0.0 & 66.67 & 0.0 & 66.67 \\
\hline
\end{tabular}

S/R $\sim$ Short-run , L/R Long-run \& $\mathrm{PT} \sim$ pass-through

Another question of considerable interest to be treated is the equality of pass-through elasticities across countries for a given industry and within a country for the different industries. This analysis allows us to examine whether international price discrimination exists. There is an important debate in economic literature about this topic. Golberg and Knetter (1997) conclude that ERPT is industry-specific and constant for a given industry across countries and Campa and Golberg (2002) add that ERPT has also been stable in time. These authors conclude that ERPT variations are due to changes in the product compositions of imports. For that reason a good procedure is to perform tests for the equality of pass-through rates across countries and industries (see Table 8). I observe that ERPT in the short-run is equal for all industries within a given country but in Slovakia. Nevertheless, in the long-run I accept that ERPT is equal for all industries within a given country. Finally, ERPT in the short-run is equal for all countries within a given industry except for Beverages and Tobacco in the short-run. This result could be due to the different taxation policies applied in each country. 
Table 8. Test of the equality of short- and long-run pass-through estimates ( $p$-values)

Across industries

\begin{tabular}{|l|l|l|}
\hline Country & S/R & $\mathbf{L} / \mathbf{R}$ \\
\hline Czech Republic & 0.4667 & 0.9798 \\
\hline Cyprus & 0.8279 & 0.9630 \\
\hline Latvia & 0.2852 & 0.6600 \\
\hline Hungary & 0.0955 & 0.4733 \\
\hline Poland & 0.2171 & 0.9998 \\
\hline Slovak Republic & $0.0377^{*}$ & 0.4867 \\
\hline Romania & 0.8810 & 0.9553 \\
\hline Turkey & 0.1302 & 0.6520 \\
\hline Slovenia & 0.7824 & 0.9970 \\
\hline
\end{tabular}

Across countries

\begin{tabular}{|l|l|l|}
\hline \multicolumn{3}{|c|}{ Across countries } \\
\hline Industry & S/R & L/R \\
\hline 0. Food and Live animals & 0.1311 & 0.3425 \\
\hline 1. Beverages and Tobacco & $0.0256^{*}$ & 0.9292 \\
\hline 2. Crude Materials & 0.5697 & 0.7210 \\
\hline 3. Mineral fuels & 0.3210 & 0.0612 \\
\hline 4. Animal, vegetable oil and fat & 0.2252 & 0.8344 \\
\hline 5.Chemicals & 0.9636 & 0.4210 \\
\hline 6. Basic manufactures & 0.2296 & 0.7854 \\
\hline 7. Vehicles and transport equipment & 0.9254 & 0.9661 \\
\hline 8. Manufactured goods & 0.7512 & 0.7326 \\
\hline
\end{tabular}

* It can be statistically rejected that the pass-through is equal to the rest at $5 \%$ significance level

\subsection{Applying de Bandt, Banerjee and Kozluk (2007) approach}

I have proved doing a ADF test for individual country/industry combinations considering specifications without or with a structural change in section 4.1 that the rejection of the null of no cointegration is very probable. Thus, If the cointegrated equilibrium relationship were to exist, the estimated equation should contain an error correction term (ECM). De Bandt, Banerjee and Kozluk (2007) propose to look at the evidence from all countries and sectors 
for the euro area. In our case the number of sectors used to be nine and the number of countries is also nine ${ }^{13}$. So, a panel-based test could use up to 9 x $9 \times 84$ observations allowing for heterogeneity. Using this test we should in principle obtain a clear idea of the common trends underlying the series and hence the existence of the long run allowing for structural change.

To build the panel I consider a pool panel in which every country and industry combination constitutes a separate unit. I use the Pedroni (1999) test for the existence of a cointegrating relationship, assuming no cross-unit interdependence ${ }^{14}$. Tables 9 and 10 offer the Pedroni (1999) break data estimates for equations (11) (break in constant) and (12) (break in both constant and slope). Some of them are very close to the date of entry to EU (Basic Manufactures in Poland, Food and lives animals, Crude Materials in Slovenia), adoption of inflation targeting (Manufactured goods in Hungary, Vehicles and Transport Equipment in Turkey) or change in the exchange rate system (Crude Materials in Slovakia). The statistics for the Pedroni (1999) panel cointegration tests indicate a strong rejection of the hypothesis of no cointegration considering the three types of long-run relationships $((9),(11)$ and $(12))^{15}$.

This implementation is very useful to explore changes in the exchange rate pass-through and cross-sectional differences at the level of these countries. Campa, Goldberg and Gonzalez-Minguez (2005) detected declines in the size of ERPT on import prices for manufacturing industries. By contrast, de Bandt, Banerjee and Kozluk (2007) find evidence for the opposite sign in the change of the pass-through in some euro area countries like Italy, Portugal and Spain. My results are very similar to the latter in the sense that some NMSs like Poland could have clearly increased the size of ERPT. If we look at carefully the Poland case we observe a different composition by product of import goods from euro area. This country has the largest share for Chemical industry $(17 \%)$ in our sample and this industry used to have a ERPT larger than the Manufacturing sector. By industries there are many divergences. it is not clear a ERPT decrease in the Manufacturing sector. I only find clear evidence for some industries in Cyprus, Latvia, Slovenia and Romania. Nevertheless it is easier to find evidence of ERPT decline in Food

\footnotetext{
${ }^{13}$ There are not available data for SITC_3 in Cyprus and SITC_4 in Cyprus and Latvia.

${ }^{14}$ De Bandt, Banerjee and Kozluk (2007) also apply the Banerjee and Carrion-i-Silvestre (2006) tests that allows a factor structure for cross-section dependence but has the limitation of imposing a common break date for the euro area countries.

${ }^{15}$ This test chooses the break data which is consistent with strongest evidence against the null and extracts the break datas for each individual series and the cointegrating coefficients.
} 
$\&$ Live Animals, Beverages and Tobacco, Crude Materials and Mineral Fuels industries.

The hypothesis of LCP (zero pass-through) is not accepted in the longrun and the hypothesis of PCP (complete pass-through) could be accepted for Food and Live Animals industry in the Czech Republic and Slovakia, Beverages and Tobacco in the Czech Republic and Cyprus, Animal, vegetable oil and fat in Romania, Chemicals in Cyprus. In manufactures industries only appears in Basic Manufactures in Latvia, Hungary and Slovakia and for Manufactured Goods in Cyprus and Slovenia. I observe again how inflation targeting countries (the Czech Republic, Hungary, Poland, Slovenia and Turkey) have a smaller size of ERPT. 
Table 9. Long-run exchange rate pass-through coefficients: break in constant

\begin{tabular}{|c|c|c|c|c|c|c|c|c|c|}
\hline & \multicolumn{3}{|c|}{ Czech Republic } & \multicolumn{3}{|l|}{ Latvia } & \multicolumn{3}{|l|}{ Cyprus } \\
\hline 1. Beverages \& Tobacco & $\begin{array}{l}0.88^{*} \\
0.12)\end{array}$ & $\begin{array}{l}1.16^{*} \\
(0.25)\end{array}$ & $6 / 04$ & $0.85^{*}$ & $\begin{array}{l}0.80^{*} \\
(0.12)\end{array}$ & $4 / 01$ & $\begin{array}{l}0.69^{*} \\
(0.34)\end{array}$ & $\begin{array}{l}1.02^{*} \\
(0.18)\end{array}$ & $1 / 03$ \\
\hline 3. Mineral fuels & $\begin{array}{l}0.1)^{2} \\
0.07)\end{array}$ & $\begin{array}{c}0.024 \\
(0.18)\end{array}$ & $5 / 04$ & $\begin{array}{l}0.14^{*} \\
(0.12)\end{array}$ & $\begin{array}{c}0.10)^{* * *} \\
(0.53)\end{array}$ & $11 / 05$ & $\frac{(0.11)}{-}$ & $\frac{(0.10)}{-}$ & $5 / 05$ \\
\hline 4. Animal, vegetable oil \& fat & $\begin{array}{l}0.51^{*} \\
(0.10)\end{array}$ & $\begin{array}{l}0.10) \\
(0.16)\end{array}$ & $4 / 05$ & $\begin{array}{l}- \\
-\end{array}$ & $\begin{array}{l}- \\
-\end{array}$ & - & - & $\begin{array}{ll}- \\
-\end{array}$ & - \\
\hline 7. Vehicles \& transport equipment & $\begin{array}{l}0.50^{*} \\
(0.10)\end{array}$ & $\begin{array}{l}0.57^{2} \\
(0.18)\end{array}$ & $8 / 03$ & $\begin{array}{l}0.81^{*} \\
(0.12)\end{array}$ & $\begin{array}{l}0.46 \\
(0.39)\end{array}$ & $10 / 04$ & $\begin{array}{l}0.69^{*} \\
(0.12)\end{array}$ & $\begin{array}{l}0.75^{*} \\
(0.22)\end{array}$ & $5 / 04$ \\
\hline 8. Manufactured goods & $\begin{array}{l}0.28^{*} \\
(0.08)\end{array}$ & $\begin{array}{l}0.47^{*} \\
(0.17)\end{array}$ & $11 / 03$ & $\begin{array}{l}0.67^{*} \\
(0.11)\end{array}$ & $\begin{array}{l}0.78^{* *} \\
(0.48)\end{array}$ & $6 / 05$ & $\begin{array}{l}1.18^{*} \\
(0.11)\end{array}$ & $\begin{array}{l}1.16^{*} \\
(0.14)\end{array}$ & $4 / 02$ \\
\hline
\end{tabular}

${ }^{*},{ }^{* *},{ }^{* * *}$ indicate whether it is significant at $1 \%, 5 \%$ and $10 \%$, respectively. 
Table 9. Long-run exchange rate pass-through coefficients break in constant (cont.)

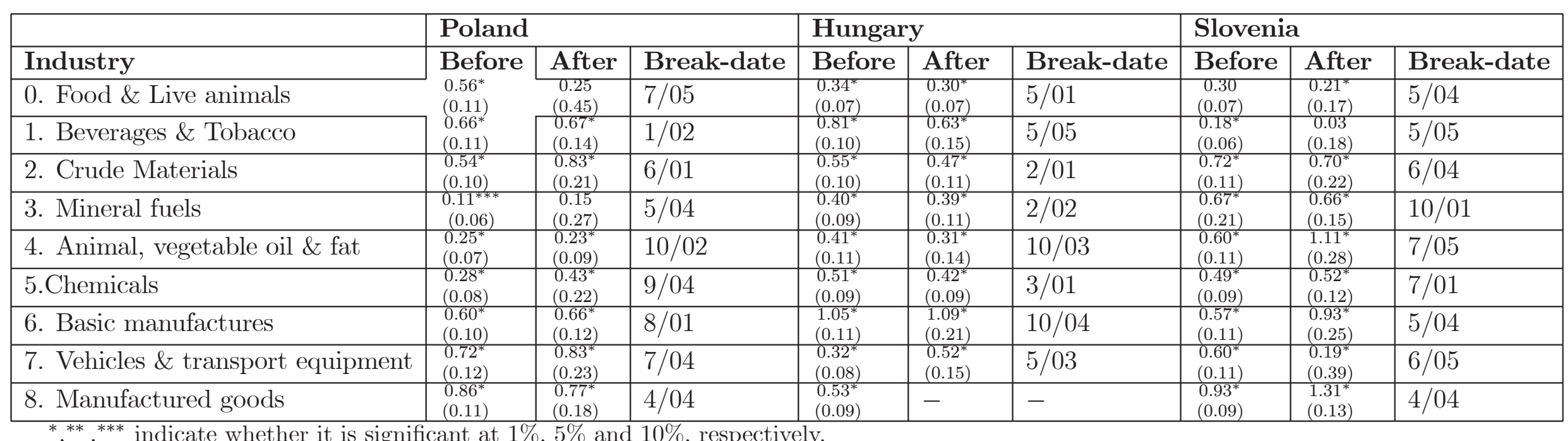

${ }^{* * *},{ }^{* *}$ indicate whether it is significant at $1 \%, 5 \%$ and $10 \%$, respectively. 
Table 9. Long-run exchange rate pass-through coefficients break in constant (cont.)

\begin{tabular}{|c|c|c|c|c|c|c|c|c|c|}
\hline & \multicolumn{3}{|c|}{ Slovakia } & \multicolumn{3}{|c|}{ Romania } & \multicolumn{3}{|l|}{ Turkey } \\
\hline Industry & Before & After & Break-date & Before & After & Break-date & Before & After & Break-date \\
\hline 0. Food \& Live animals & $\begin{array}{l}0.73^{*} \\
(0.13)\end{array}$ & $\begin{array}{l}1.19^{*} \\
(0.29)\end{array}$ & $5 / 04$ & $\begin{array}{l}0.31^{*} \\
(0.13)\end{array}$ & $\begin{array}{l}0.51^{*} \\
(0.59)\end{array}$ & $9 / 05$ & $\begin{array}{c}0.17 \\
(0.06)\end{array}$ & $\begin{array}{l}0.05^{\pi} \\
(0.12)\end{array}$ & $5 / 04$ \\
\hline 1. Beverages \& Tobacco & $\begin{array}{l}0.64^{*} \\
(0.11)\end{array}$ & $\begin{array}{l}0.54^{2} \\
(0.13)\end{array}$ & $3 / 02$ & $\begin{array}{l}0.62 \\
(0.11)\end{array}$ & $\begin{array}{l}0.40^{*} \\
(0.17)\end{array}$ & $3 / 04$ & $\begin{array}{l}0.50^{2} \\
(0.10)\end{array}$ & $\begin{array}{l}0.36^{*} \\
(0.11)\end{array}$ & $8 / 02$ \\
\hline 2. Crude Materials & $\begin{array}{l}0.38^{*} \\
(0.11)\end{array}$ & $\begin{array}{l}0.02^{*} \\
(0.19)\end{array}$ & $8 / 01$ & $\begin{array}{l}0.68^{*} \\
(0.11)\end{array}$ & $\begin{array}{l}0.69^{*} \\
(0.13)\end{array}$ & $3 / 01$ & $\begin{array}{l}0.51^{*} \\
(0.10)\end{array}$ & $\begin{array}{l}0.36^{*} \\
(0.12)\end{array}$ & $5 / 02$ \\
\hline 3. Mineral fuels & $\begin{array}{l}0.33^{*} \\
(0.10) \\
\end{array}$ & $\begin{array}{l}0.29^{*} \\
(0.09) \\
\end{array}$ & $10 / 05$ & $\begin{array}{l}0.72^{*} \\
(0.11) \\
\end{array}$ & $\begin{array}{l}0.77^{*} \\
(0.27)\end{array}$ & $8 / 04$ & $\begin{array}{l}0.61^{*} \\
(0.11)\end{array}$ & $\begin{array}{l}- \\
-\end{array}$ & - \\
\hline 4. Animal, vegetable oil \& fat & $\begin{array}{l}0.64^{*} \\
(0.11)\end{array}$ & $\begin{array}{l}0.60^{*} \\
(0.12)\end{array}$ & $6 / 01$ & $\begin{array}{l}1.14^{*} \\
(0.11)\end{array}$ & $\begin{array}{ll}- \\
-\end{array}$ & - & $\begin{array}{l}0.46^{*} \\
(0.09)\end{array}$ & $\begin{array}{l}0.44^{*} \\
(0.13)\end{array}$ & $7 / 03$ \\
\hline 5.Chemicals & $\begin{array}{l}0.26^{*} \\
(0.07)\end{array}$ & $\begin{array}{l}0.24^{*} \\
(0.08)\end{array}$ & $4 / 01$ & $\begin{array}{l}0.48^{*} \\
(0.10) \\
\end{array}$ & $\begin{array}{l}0.57^{*} \\
(0.26)\end{array}$ & $8 / 04$ & $\begin{array}{l}0.86^{*} \\
(0.12) \\
\end{array}$ & $\begin{array}{l}0.97^{*} \\
(0.17)\end{array}$ & $5 / 03$ \\
\hline 6. Basic manufactures & $\begin{array}{l}0.55^{*} \\
(0.11)\end{array}$ & $\begin{array}{l}0.94^{*} \\
(0.28) \\
\end{array}$ & $8 / 04$ & $\begin{array}{l}0.69^{*} \\
(0.11)\end{array}$ & $\begin{array}{l}0.98^{*} \\
(0.27)\end{array}$ & $5 / 04$ & $\begin{array}{l}0.25^{*} \\
(0.09)\end{array}$ & $\begin{array}{l}0.42^{*} \\
(0.19)\end{array}$ & $5 / 04$ \\
\hline 7. Vehicles \& transport equipment & $\begin{array}{l}0.54^{*} \\
(0.10)\end{array}$ & $\begin{array}{l}0.65^{*} \\
(0.21)\end{array}$ & $3 / 04$ & $\begin{array}{l}0.71^{*} \\
(0.12)\end{array}$ & $\begin{array}{ll}- \\
-\end{array}$ & - & $\begin{array}{l}0.62^{*} \\
(0.11)\end{array}$ & $\begin{array}{l}0.52^{*} \\
(0.12)\end{array}$ & $2 / 03$ \\
\hline 8. Manufactured goods & $\begin{array}{l}0.67^{*} \\
(0.11)\end{array}$ & $\begin{array}{l}0.89^{*} \\
(0.35)\end{array}$ & $5 / 05$ & $\begin{array}{l}0.37^{*} \\
(0.08)\end{array}$ & $\begin{array}{c}0.30^{* * *} \\
(0.16) \\
\end{array}$ & $5 / 05$ & $\begin{array}{l}0.47^{*} \\
(0.09)\end{array}$ & $\begin{array}{l}0.51^{*} \\
(0.11)\end{array}$ & $9 / 01$ \\
\hline
\end{tabular}

$*^{* *},{ }^{* *}$ indicate whether it is significant at $1 \%, 5 \%$ and $10 \%$, respectively. 
Table 10. Long-run exchange rate pass-through coefficients break in constant and slope

\begin{tabular}{|c|c|c|c|c|c|c|c|c|c|}
\hline & \multicolumn{3}{|c|}{ Czech Republic } & \multicolumn{3}{|l|}{ Latvia } & \multicolumn{3}{|l|}{ Cyprus } \\
\hline Industry & Before & After & Break-date & Before & After & Break-date & Before & After & Break-date \\
\hline 0. Food \& Live animals & $\begin{array}{l}0.56^{*} \\
(0.12)\end{array}$ & $\begin{array}{l}0.78^{*} \\
(0.22)\end{array}$ & $1 / 03$ & $\begin{array}{l}0.64^{*} \\
(0.11)\end{array}$ & $\begin{array}{l}0.65^{*} \\
(0.14)\end{array}$ & $9 / 02$ & $\begin{array}{l}0.77^{*} \\
(0.11)\end{array}$ & $\begin{array}{l}- \\
-\end{array}$ & - \\
\hline 1. Beverages \& Tobacco & $\begin{array}{l}0.92^{*} \\
(0.12) \\
\end{array}$ & $\begin{array}{l}- \\
- \\
\end{array}$ & & $\begin{array}{l}0.75^{*} \\
(0.11)\end{array}$ & $\begin{array}{l}- \\
- \\
\end{array}$ & & $\begin{array}{l}0.84^{*} \\
(0.11)\end{array}$ & $\begin{array}{l}- \\
-\end{array}$ & - \\
\hline 2. Crude Materials & $\begin{array}{l}0.10^{* *} \\
(0.05)\end{array}$ & $\begin{array}{l}0.50^{\text {** }} \\
(0.26) \\
\end{array}$ & $5 / 05$ & $\begin{array}{l}0.72^{*} \\
(0.13)\end{array}$ & $\begin{array}{c}0.22 \\
(0.62) \\
\end{array}$ & $10 / 05$ & $\begin{array}{l}0.38^{*} \\
(0.09)\end{array}$ & $\begin{array}{l}0.57^{*} \\
(0.46)\end{array}$ & $3 / 06$ \\
\hline 3. Mineral fuels & $\begin{array}{l}0.11^{*} \\
(0.07)\end{array}$ & $\begin{array}{c}0.18 \\
(0.17) \\
\end{array}$ & $5 / 04$ & $\begin{array}{l}0.76^{*} \\
(0.11)\end{array}$ & $\begin{array}{ll}- \\
- \\
\end{array}$ & - & $\begin{array}{ll}- \\
- \\
\end{array}$ & $\begin{array}{ll}- \\
- \\
\end{array}$ & - \\
\hline 4. Animal, vegetable oil \& fat & $\begin{array}{l}0.36^{*} \\
(0.09)\end{array}$ & $\begin{array}{l}0.59^{* *} \\
(0.39)\end{array}$ & $2 / 05$ & $\begin{array}{l}(0.11) \\
- \\
-\end{array}$ & $\begin{array}{l}- \\
- \\
-\end{array}$ & - & $\begin{array}{l}- \\
- \\
-\end{array}$ & $\begin{array}{ll}- \\
-\end{array}$ & - \\
\hline 5.Chemicals & $\begin{array}{l}0.28^{*} \\
(0.08)\end{array}$ & $\begin{array}{l}0.36^{* *} \\
(0.20)\end{array}$ & $10 / 04$ & $\begin{array}{l}0.68^{*} \\
(0.11)\end{array}$ & $\begin{array}{l}- \\
-\end{array}$ & - & $\begin{array}{l}1.03^{*} \\
(0.11)\end{array}$ & $\begin{array}{l}- \\
-\end{array}$ & - \\
\hline 6. Basic manufactures & $\begin{array}{l}0.21^{*} \\
(0.07)\end{array}$ & $\begin{array}{c}0.94 \\
(0.42) \\
\end{array}$ & $8 / 04$ & $\begin{array}{l}0.80^{*} \\
(0.12)\end{array}$ & $\begin{array}{l}1.00^{*} \\
(0.16)\end{array}$ & $1 / 02$ & $\begin{array}{l}0.117 \\
0.10)\end{array}$ & $\begin{array}{l}0.45^{*} \\
(0.13)\end{array}$ & $8 / 04$ \\
\hline 7. Vehicles \& transport equipment & $\begin{array}{l}0.62^{*} \\
(0.11)\end{array}$ & $\begin{array}{l}1.03^{*} \\
(0.20)\end{array}$ & $8 / 03$ & $\begin{array}{l}0.68^{*} \\
(0.11)\end{array}$ & $\begin{array}{ll}- \\
-\end{array}$ & - & $\begin{array}{l}0.65^{*} \\
(0.09)\end{array}$ & $\begin{array}{ll}- \\
-\end{array}$ & - \\
\hline 8. Manufactured goods & $\begin{array}{l}0.76^{*} \\
(0.12) \\
\end{array}$ & $\begin{array}{l}0.64^{*} \\
(0.20)\end{array}$ & $11 / 03$ & $\begin{array}{l}0.61^{*} \\
(0.10)\end{array}$ & $\begin{array}{ll}- \\
-\end{array}$ & - & $\begin{array}{l}1.04^{*} \\
(0.11)\end{array}$ & $\begin{array}{l}- \\
-\end{array}$ & - \\
\hline
\end{tabular}

$*^{* *},{ }^{* * *}$ indicate whether it is significant at $1 \%, 5 \%$ and $10 \%$, respectively. 
Table 10. Long-run exchange rate pass-through coefficients break in constant and slope (cont.)

\begin{tabular}{|c|c|c|c|c|c|c|c|c|c|}
\hline & \multicolumn{3}{|l|}{ Poland } & \multicolumn{3}{|c|}{ Hungary } & \multicolumn{3}{|c|}{ Slovenia } \\
\hline Industry & Before & After & Break-date & Before & After & Break-date & Before & After & Break-date \\
\hline 1. Beverages \& Tobacco & $\begin{array}{l}0.53^{*} \\
(0.10)\end{array}$ & - & - & $\begin{array}{l}0.81^{2} \\
(0.11)\end{array}$ & $\begin{array}{l}0.62 * \\
(0.15)\end{array}$ & $5 / 05$ & $\begin{array}{l}0.05 \\
(0.07)\end{array}$ & $\begin{array}{c}0.42 \\
(0.20)\end{array}$ & $5 / 05$ \\
\hline 3. Mineral fuels & $\begin{array}{l}0.11^{*} \\
(0.06)\end{array}$ & $\begin{array}{l}0.24^{*} \\
(0.12)\end{array}$ & $5 / 04$ & $\begin{array}{l}0.46^{*} \\
(0.09)\end{array}$ & $\begin{array}{l}0.42^{*} \\
(0.11)\end{array}$ & $2 / 02$ & $\begin{array}{l}0.84^{*} \\
(0.21)\end{array}$ & $\begin{array}{l}0.91^{*} \\
(0.15)\end{array}$ & $10 / 01$ \\
\hline 4. Animal, vegetable oil \& fat & $\begin{array}{l}0.18^{*} \\
(0.07)\end{array}$ & $\begin{array}{l}.76^{*} \\
(0.32)\end{array}$ & $1 / 06$ & $\begin{array}{l}0.84^{*} \\
(0.11)\end{array}$ & $\begin{array}{l}0.88^{*} \\
(0.14)\end{array}$ & $10 / 03$ & $\begin{array}{l}0.70^{*} \\
(0.12)\end{array}$ & $\begin{array}{l}1.17^{*} \\
(0.22)\end{array}$ & $9 / 04$ \\
\hline 7. Vehicles \& transport equipment & $\begin{array}{l}0.71^{*} \\
(0.12)\end{array}$ & $\begin{array}{l}0.86^{*} \\
(0.24)\end{array}$ & $7 / 04$ & $\begin{array}{l}0.33^{*} \\
(0.09)\end{array}$ & $\begin{array}{l}0.41^{*} \\
(0.11)\end{array}$ & $7 / 01$ & $\begin{array}{l}0.78^{*} \\
(0.12)\end{array}$ & $\begin{array}{l}0.54 \\
(0.34)\end{array}$ & $4 / 05$ \\
\hline 8. Manufactured goods & $\begin{array}{l}0.81^{2} \\
(0.11)\end{array}$ & - & - & $\begin{array}{l}0.59^{*} \\
(0.09)\end{array}$ & - & - & $\begin{array}{l}0.82^{*} \\
(0.15)\end{array}$ & $\begin{array}{l}1.31^{*} \\
(0.27)\end{array}$ & $3 / 05$ \\
\hline
\end{tabular}

${ }^{*},{ }^{* *},{ }^{* * *}$ indicate whether it is significant at $1 \%, 5 \%$ and $10 \%$, respectively. 
Table 10. Long-run exchange rate pass-through coefficients: break in constant and slope(cont.)

\begin{tabular}{|c|c|c|c|c|c|c|c|c|c|}
\hline & \multicolumn{3}{|c|}{ Slovakia } & \multicolumn{3}{|c|}{ Romania } & \multicolumn{3}{|l|}{ Turkey } \\
\hline Industry & Before & After & Break-date & Before & After & Break-date & Before & After & Break-date \\
\hline 0. Food \& Live animals & $\begin{array}{l}0.67^{*} \\
(0.11)\end{array}$ & $\begin{array}{l}0.82^{*} \\
(0.20)\end{array}$ & $9 / 02$ & $\begin{array}{l}0.29^{*} \\
(0.13)\end{array}$ & $\begin{array}{l}- \\
-\end{array}$ & - & $\begin{array}{c}0.31 \\
(0.09)\end{array}$ & $\begin{array}{c}0.21 \\
(0.18)\end{array}$ & $5 / 04$ \\
\hline 1. Beverages \& Tobacco & $\begin{array}{l}0.56^{*} \\
(0.11)\end{array}$ & $\begin{array}{l}0.48^{2} \\
(0.20)\end{array}$ & $5 / 04$ & $\begin{array}{l}0.70^{*} \\
(0.11)\end{array}$ & $\begin{array}{l}0.59^{*} \\
(0.12)\end{array}$ & $3 / 04$ & $\begin{array}{l}0.51^{2} \\
(0.11)\end{array}$ & $\begin{array}{l}0.38^{2} \\
(0.12)\end{array}$ & $8 / 02$ \\
\hline 2. Crude Materials & $\begin{array}{l}0.43^{*} \\
(0.11)\end{array}$ & $\begin{array}{l}0.39^{*} \\
(0.11)\end{array}$ & $1 / 02$ & $\begin{array}{l}0.65^{*} \\
(0.10)\end{array}$ & $\begin{array}{l}0.69^{*} \\
(0.09)\end{array}$ & $3 / 01$ & $\begin{array}{l}0.42^{*} \\
(0.09)\end{array}$ & $\begin{array}{l}1.84^{*} \\
(0.32)\end{array}$ & $3 / 06$ \\
\hline 3. Mineral fuels & $\begin{array}{l}0.33^{*} \\
(0.09) \\
\end{array}$ & $\begin{array}{c}0.35 \\
(0.33)\end{array}$ & $2 / 01$ & $\begin{array}{c}0.74^{*} \\
(0.10) \\
\end{array}$ & $\begin{array}{l}1.04^{*} \\
(0.11) \\
\end{array}$ & $8 / 04$ & $\begin{array}{l}0.61^{*} \\
(0.11)\end{array}$ & $\begin{array}{l}- \\
- \\
\end{array}$ & - \\
\hline 4. Animal, vegetable oil \& fat & $\begin{array}{l}0.75^{*} \\
(0.10)\end{array}$ & $\begin{array}{l}0.82^{*} \\
(0.44)\end{array}$ & $6 / 05$ & $\begin{array}{c}0.09 \\
(0.12)\end{array}$ & $\begin{array}{l}- \\
-\end{array}$ & - & $\begin{array}{l}0.43^{*} \\
(0.09)\end{array}$ & $\begin{array}{l}0.76^{*} \\
(0.39)\end{array}$ & $4 / 06$ \\
\hline 5.Chemicals & $\begin{array}{l}0.26^{*} \\
(0.07)\end{array}$ & $\begin{array}{l}0.25^{*} \\
(0.08)\end{array}$ & $3 / 01$ & $\begin{array}{l}0.40^{*} \\
(0.09)\end{array}$ & $\begin{array}{l}0.76^{*} \\
(0.10)\end{array}$ & $8 / 04$ & $\begin{array}{l}0.94^{*} \\
(0.13)\end{array}$ & $\begin{array}{l}1.26^{*} \\
(0.17)\end{array}$ & $5 / 03$ \\
\hline 6. Basic manufactures & $\begin{array}{l}0.64^{*} \\
(0.12)\end{array}$ & $\begin{array}{l}1.59^{*} \\
(0.31)\end{array}$ & $5 / 04$ & $\begin{array}{l}0.91^{*} \\
(0.11)\end{array}$ & $\begin{array}{l}1.641^{*} \\
(0.11)\end{array}$ & $3 / 06$ & $\begin{array}{l}0.34^{*} \\
(0.10)\end{array}$ & $\begin{array}{l}0.43^{*} \\
(0.21)\end{array}$ & $5 / 04$ \\
\hline 7. Vehicles \& transport equipment & $\begin{array}{l}0.63^{*} \\
(0.11)\end{array}$ & $\begin{array}{l}0.81^{*} \\
(0.53)\end{array}$ & $1 / 05$ & $\begin{array}{l}0.75^{*} \\
(0.12)\end{array}$ & $\begin{array}{l}- \\
-\end{array}$ & - & $\begin{array}{l}0.51^{*} \\
(0.09)\end{array}$ & $\begin{array}{l}0.99^{*} \\
(0.16)\end{array}$ & $6 / 01$ \\
\hline 8. Manufactured goods & $\begin{array}{l}0.48^{*} \\
(0.10)\end{array}$ & $\begin{array}{l}0.79^{*} \\
(0.18)\end{array}$ & $2 / 03$ & $\begin{array}{l}0.40^{*} \\
(0.08)\end{array}$ & $\begin{array}{l}0.38^{* *} \\
(0.18)\end{array}$ & $5 / 05$ & $\begin{array}{l}0.66^{*} \\
(0.12)\end{array}$ & $\begin{array}{ll}- \\
-\end{array}$ & $\begin{array}{ll}- \\
-\end{array}$ \\
\hline
\end{tabular}

${ }^{*},{ }^{* *},{ }^{* *}$ indicate whether it is significant at $1 \%, 5 \%$ and $10 \%$, respectively. 


\section{Exchange rate pass-through to the cost of intermediate consumption and final consump- tion prices}

Some empirical results and theoretical models suggest a decline in the ERPT along the pricing chain. Therefore, a stronger and quicker ERPT is expected for IUVs, followed by producer prices and finally by Harmonized Consumer Prices Indexes ${ }^{16}$. Next, I proceed to examine what is the ERPT of exchange rate movements into the aggregate consumer price index of a country (final consumption imported goods) and into the overall cost of production (imported inputs).

By examining the impact of exchange rate movements into the aggregate consumer price index of a country and into the overall cost production, we can evaluate respectively, the ERPT due to goods imported for final consumption or imported inputs. As Campa and Gonzalez-Minguez (2006) point out an approximation to the aggregated transmission of the exchange rate movements to the overall costs of production and to consumer prices can be computed through a weighted aggregation of the pass-through rates obtained for the import prices of each type of product. I take as a starting point the previous evidence that, in the long run, ERPT is similar across industries of a given country and across countries for a given industry, implying the differential ERPT rates across countries are not likely to be great due to differences in industry composition.

From that objective I follow Campa and Gonzalez-Minguez (2006) by considering a price index for country $i$ as the result of two successive decompositions ${ }^{17}$. The first decomposition allow us to express the price index as a weighted average of the different products entering the index:

$$
P I=\prod_{j}\left(p_{t}^{i, j}\right)^{w_{t}^{i, j}}
$$

where $w_{t}^{i, j}$ is the weight of the product category $\mathrm{j}$ in the aggregate index of country i. So, we can disaggregate the component referring to each

\footnotetext{
${ }^{16}$ Hanhn (2003) obtains evidence of ERPT decline along the pricing chain for euro area.

${ }^{17}$ Campa and Gonzalez-Mínguez (2006) indicate that an approximation to the aggregated transmission of exchange rate movements to overall costs of production and to consumer prices can be computed through a weighted aggregation of the pass-through rates obtained obtained for the import prices of each type of product.
} 
product category into three components, which are defined according to the geographical origin of the products.

$$
P I^{i}=\prod_{j d}\left(p_{t}^{i, j d}\right)^{w_{t}^{i, j d}} \prod_{j n}\left(p_{t}^{i, j n}\right)^{w_{t}^{i, j n}} \prod_{j e}\left(p_{t}^{i, j e}\right)^{w_{t}^{i, j e}}
$$

where $j d, j n$ and $j e$ indicate the shares of its final or intermediate consumption which are satisfied by products produced domestically, in other non- euro area countries and in euro area countries, respectively.

Taking first differences of the logs of that expression and assuming that the weights are constant over time we obtain that:

$$
\hat{P}^{i}=\sum_{j d} w_{t}^{i, j d} \hat{p}_{t}^{i, j d}+\sum_{j n} w_{t}^{i, j n} \hat{p}_{t}^{i, j n}+\sum_{j e} w_{t}^{i, j e} \hat{p}_{t}^{i, j e}
$$

where $\hat{P}$ is the inflation.

The previous equation shows that the effect on aggregate prices can be decomposed in the sum of these three components. We usually consider in previous sections that the ERPT examines the last term of the right-hand side of the equation by assuming the other two terms are zero. By estimating equation (10) we are considering that ERPT to price of goods produced domestically or non-euro area countries is zero. This term captures the direct effect arising from the pass-through to the prices of products imported from the euro area. For each product category this effect can be decomposed in two parts: the weight of imported products inside the euro area in the price index,$w_{t}^{i, j e}$ (i.e. the openness of the country when aggregating across products), and the rate of pass-through from exchange rates into import prices. Therefore, we expect that the higher the weight of euro area imported goods in the price index the higher will be the impact of any rate off passthrough from exchange rates into import prices in the aggregated price index. The share of imports from euro area within total imports is very high in all these countries and it could be obtained using both the input-output tables for each country and the Comext database. In case of intermediate consumption the input-output table would indicate for every industry in each country the decomposition of intermediate consumptions between those which are domestically produced and those that are imported. In a similar way, in the case of consumption goods, the table would show which part of the demand for each product is satisfied through domestic production and imports. Obviously, these tables have a product disaggregation much larger and it would be necessary to match them in our 9 categories. Nevertheless, we have several restrictions. First, among imported products, what the tables 
do not show is the decomposition according to the euro area origin (only intra European Union and extra European Union). Second, we only have detailed data according that origin for Poland and Slovenia in our sample. For that reason it is necessary to use the Comext database since it offers the share of imports coming inside the euro area within total imports. Finally, given the lack of detailed information, we needed to make the assumption that, for each good entering the production process as intermediate consumptions, the share of imports originated inside the area within total imports is the same for all the industries producing final goods The main hypothesis is made when the product is final instead of intermediate consumption.

Next, I did the decomposition of the price index of the products used as intermediate inputs in the production process and the consumer price index. I exclude Turkey and Romania from the exercise of the consumer price index plus Latvia from the cost of intermediation exercise because there is not enough data available. Table 11 and 12 offer us the main results of the impact of a $10 \%$ depreciation of the exchange rate of the euro. Divergences in ERPT can be due to two sources: (i) differences in the degree of openness of member countries and (ii) for a given degree of openness, differences in the product composition of imports can also result in differences in ERPT and if product-specific ERPT rates vary a lot in relation to the industry. In order to examine this effect I estimate ERPT by considering the own degree of openness and by imposing the same degree of openness (average) in all countries.

Table 11 shows the estimated ERPT to cost of intermediate consumption. The first part corresponds to the aggregated rates calculated for each country under its own degree of exposure to euro area imports. In this observed case, differences are solely due to the heterogeneity in the degree of openness and/or the industry composition of trade. In the second part, the degree of trade openness is average and the remaining differences are solely due to the heterogeneity in the structure of their imports of inputs. The highest ERPT are obtained in Slovenia and Hungary. By contrast Cyprus, Poland and Slovakia have the lowest. In the second part of Table 11 we can see how differences remain and the range is between 0.11 and 1.03. The average ERPT is smaller (0.371) than the derived for the long-run using import prices $(0.631)$ 
Table 11. Pass-through rates to cost of intermediate consumption (for a $10 \%$ depreciation) test of equality against the average

A. Under own degree of openness

\begin{tabular}{|l|l|l|}
\hline Country & PT value & F-test against the unweighted average \\
\hline Czech Republic & 0.11 & $0.14^{*}$ \\
\hline Cyprus & 0.20 & $0.31^{*}$ \\
\hline Hungary & 0.37 & $0.99^{*}$ \\
\hline Poland & 0.17 & $0.22^{*}$ \\
\hline Slovak Republic & 0.29 & $0.60^{*}$ \\
\hline Slovenia & 1.08 & 0.00 \\
\hline Average & $\mathbf{0 . 3 7}$ & \\
\hline
\end{tabular}

B. Under the average degree of openness

\begin{tabular}{|l|l|l|}
\hline Country & PT value & F-test against the unweighted average \\
\hline Czech Republic & 0.11 & $0.13^{*}$ \\
\hline Cyprus & 0.20 & $0.30^{*}$ \\
\hline Hungary & 0.38 & $0.95^{*}$ \\
\hline Poland & 0.17 & $0.21^{*}$ \\
\hline Slovak Republic & 0.30 & $0.62^{*}$ \\
\hline Slovenia & 1.07 & 0.00 \\
\hline Average & $\mathbf{0 . 3 7}$ & \\
\hline
\end{tabular}

${ }^{*}, * *$ indicate the null hypothesis cannot be rejected at $95 \%$ and $90 \%$ significance level, respectively. 
Table 12 includes the ERPT to consumer price indices on the face of a $10 \%$ depreciation of the euro. The higher rates are offered again by Hungary, Slovakia, Slovenia and Latvia. If we observe the pricing chain we find evidence in favour of a decline in the ERPT because the average is slightly smaller (0.34) than the derived for ERPT to consumer prices (0.37). For instance, in the Czech Republic long-run ERPT to UIVs ranges is 0.24, ERPT to cost of intermediation is 0.17 and to final consumption is 0.11 . Using the same structural breaks than in the previous section I also find evidence of a ERPT decline for cost of intermediation and final consumption goods ${ }^{18}$.

Finally, I observe to what extent the calculated differences in total ERPT are significant doing a equality test of calculated ERPT against their unweighted averages. I must point out that testing against the unweighted average has the potential disadvantage that, in the case that a small country would have a total pass-through rate which is much different from the others, the unweighted average would tend to be biased towards the pass-through value for that country. Therefore, the equality of total rates to their average would tend to be rejected for the other countries. While in fact, apart from the outlier, could be clustered around a small range of values. For the cost of intermediate consumption the equality of ERPT to average is statistically rejected for Slovenia. In case of final consumption this hypothesis is rejected for Poland, Slovenia and Latvia ${ }^{19}$. If we look carefully at the results under own degree of openness and under the average degree of openness for cost of intermediate inputs we observe how the large dependence of their economies to imported inputs (openness) is not a relevant factor to explain size of the ERPT to the cost of intermediation. For final consumption we obtain different results and the amount of imported goods seems to be more relevant.

\footnotetext{
${ }^{18}$ These results are not offered for the sake of brevity.

${ }^{19}$ I repeat the same test using weighted averages by the relative size of each country's GDP but the main results remain.
} 
Table 12. Pass-through rates to final consumption prices (for a $10 \%$ depreciation): test of equality against the average

A. Under own degree of openness

\begin{tabular}{|l|l|l|}
\hline Country & PT value & F-test against the unweighted average \\
\hline Czech Republic & 0.17 & $0.01^{*}$ \\
\hline Cyprus & 0.21 & 0.04 \\
\hline Latvia & 0.36 & $0.67^{*}$ \\
\hline Hungary & 0.49 & 0.02 \\
\hline Poland & 0.24 & $0.10^{*}$ \\
\hline Slovak Republic & 0.47 & 0.03 \\
\hline Slovenia & 0.42 & $0.14^{*}$ \\
\hline Average & $\mathbf{0 . 3 4}$ & \\
\hline
\end{tabular}

B. Under the average degree of openness

\begin{tabular}{|l|l|l|}
\hline Country & PT value & F-test against the unweighted average \\
\hline Czech Republic & 0.11 & 0.03 \\
\hline Cyprus & 0.14 & $0.06^{* *}$ \\
\hline Latvia & 0.24 & $0.58^{*}$ \\
\hline Hungary & 0.32 & 0.02 \\
\hline Poland & 0.12 & 0.03 \\
\hline Slovak Republic & 0.31 & 0.03 \\
\hline Slovenia & 0.28 & $0.13^{*}$ \\
\hline Average & $\mathbf{0 . 2 2}$ & \\
\hline
\end{tabular}

*,**indicate the null hypothesis cannot be rejected at $95 \%$ and $90 \%$ significance level, respectively. 


\section{Conclusions}

In this paper, I have studied the ERPT changes into the prices of imports made by some New Member States (NMSs) of the European Union and one candidate country, Turkey, that originated inside the Euro area. I have used data on import unit values for nine different product categories for each country and I have estimated industry-specific rates of pass-through across and within countries using two different methodological approaches: (i) the Campa and González-Mínguez (2006) approach which estimates the short- and long-run pass through elasticities, where long-run elasticities are defined as the sum of the pass-through coefficients for the contemporaneous exchange rate and its first four lags and (ii) de Bandt, Banerjee and Tomasz Kozluk (2007) approach which suggests a long-run Engle and Granger (1987) cointegrating relationship and the possibility of structural breaks to restore the long-run in the estimation.

By applying both methodologies, I observe that the hypothesis of LCP (zero pass-through) cannot be rejected for all the countries and the hypothesis of PCP (complete pass-through) is clearly rejected for all the countries except Slovenia and Cyprus. The short-run elasticities are larger for Cyprus, Slovenia and Latvia and smaller for Turkey, Romania, Poland, the Czech Republic and Hungary. In the long-run ERPT is slightly smaller and again the largest values are in Cyprus, Latvia and Slovenia and the smallest in Turkey, Romania, Poland and the Czech Republic.

When examining different European countries, the Czech Republic, Poland and Turkey have the smallest pass-through and they have adopted inflation targeting in their monetary policies and owns a flexible exchange rate system. This could give support and evidence in favour of Taylor's (2001) hypothesis. Second, the expected positive relationship between openness and the estimated long-run ERPT is derived for Slovenia and Hungary but not for Cyprus where we should expect a smaller long-run ERPT. With reference to theory and the results by industry, we can see how elasticities are lower in Basic Manufactures, Chemicals and Manufactured Goods.

The second methodology allow us to derive results very similar to de Bandt, Banerjee and Kozluz (2007) in the sense that some NMSs like Poland could have clearly increased the size of ERPT. By industries there are many divergences and it is not completely clear a ERPT decrease in the Manufacturing sector. I only found clear evidence for some industries in Cyprus, Latvia, Slovenia and Romania. Nevertheless it is easier to find evidence of ERPT decline in Food $\&$ Live Animals, Beverages and Tobacco, Crude Materials and Mineral Fuels industries. 
Finally, I observe the main results to the impact of a $10 \%$ depreciation of the exchange rate of the euro to the cost of intermediation consumption and to final consumption prices considering that divergences in ERPT can be due to two sources:(i) differences in the degree of openness of member countries and (ii) for a given degree of openness, differences in the product composition of imports. The highest ERPT to the cost of intermediation consumption is obtained in Slovenia and Hungary. In contrast Cyprus, Poland and Slovakia have the lowest. The higher rates of ERPT to consumer prices are offered again by Hungary, Slovakia, Slovenia and Latvia. If we observe the pricing chain we find evidence in favour of a decline in the ERPT along the pricing chain. We observe a large dependence of their economies on imported inputs (openness) which is a relevant factor to explain size of the ERPT for final consumption.

My further research should be centered on analysing more directly the role played by those micro and macro factors pointed out in section 2 and taking into account other factors like distribution costs, transportation charges, taxes and margin of distributors. I would also try to explain the observed degree of pass through and to study its structural determinants through a small open economy DSGE model featuring a number of characteristics that are likely to influence the response of domestic prices to changes in exchange rates and estimating a VAR for each country. 


\section{References}

[1] BACHETTA, P., and E. Van WINCOOP (2003). "Why do consumers prices react less than import prices to exchange rates?", Journal of the European Economic Association, 1, pp. 662-670.

[2] BUSSIERE, M., and T. PELTOVEN (2007). Export and import prices in emerging markets: What role for exchange rate pass-through?, mimeo, European Central Bank.

[3] CAMPA, J. M., L. GOLBERG and J. M. GONZÁLEZ-MÍNGUEZ (2005). Exchange Rate Pass-Through to Import Prices in the Euro Area, NBER Working Paper No. 11632.

[4] CAMPA, J. M., and J. M. GONZÁLEZ-MÍNGUEZ (2006). "Differences in Exchange Rate Pass-Through in the Euro Area", European Economic Review, 50, pp. 121-145.

[5] CA'ZORZI, M., E. KAHN and M. SÁNCHEZ (2007). Exchange Rate Pass-Through in Emerging Markets, ECB Working Papers Series No. 739.

[6] CORICELLI, F., J. BOSTJAN and I. MASTEN (2003). Exchange rate pass-through in Candidate Countries, Center for Economic Policy Research Discussion Paper No. 3894.

[7] CORSETTI, G., L. DEDOLA and S. LEDUC (2006). DSGE Models of High Exchange Rate Volatility and Low Pass-Through, CEPR Discussion Paper No. 5377.

[8] CORSETTI, G., and P. PRESENTI (2001). "Welfare and Macroeconomic Interdependence", Quarterly Journal Economics, 116 (2), pp. 421-446.

[9] — (2001). "International Dimensions of Optimal Monetary Policy", Journal of Monetary Economics, 52, pp. 281-305.

[10] DE BANDT, O., A. BANERJEE and T. KOZLUK (2007). Measuring Long Run Exchange Rate Pass-Through, mimeo, European University Institute.

[11] DARVAS, Z. (2001). Exchange rate pass-though and real exchange rate in EU Candidate Countries, Deutsche Bundesbank Discussion Paper No. 3894. 
[12] DEVEREUX, M. (2000). "Monetary Policy, exchange rate flexibility and Exchange Rate Pass-Through", in Revisiting the Case for flexible Exchange Rates, Bank of Canada, pp. 47-82.

[13] DEVEREUX, M., and C. ENGEL (2002). "Exchange Rate PassThrough, Exchange Rate Volatility, and Exchange Rate Disconnect", Journal of Monetary Economics, 49, pp. 913-940.

[14] DEVEREUX, M., C. ENGEL and C. TILLE (2003). "Exchange Rate Pass-Through and the Welfare Effects of the Euro", International Economic Review, 44, pp. 223-249.

[15] ENGLE, R. and C. GRANGER (1987). "Cointegration and error correction: representation, estimation and testing", Econometrica, 55, pp. 251-276.

[16] FRANKEL, J., D. PARSLEY and S. WEI (2005). Slow Pass-Through Around the World: A New Import for Developing Countries?, NBER Working Paper No. 11199.

[17] GUST, C., S. LEDUC and R. J. VIGFUSSON (2006). Trade Integration, competition, and the decline in exchange rate pass-through, International Finance Discussion Paper No. 864, August 2006, Federal Reserve Board.

[18] HAHN, E. (2003). Pass-through of External Shocks to Euro Area Inflation, ECB Working Paper No. 243.

[19] MARAZZI, M., N. SHEETS, R. VIGFUSSON, J. FAUST, J. GAGNON, J. MÁRQUEZ, R. MARTIN, T. REVVE and J. ROGERS (2005). Exchange Rate Pass-Through to U.S. Import Prices: Some New Evidence, The Federal Reserve Board International Finance Discussion Papers 2005-833.

[20] MENON, J. (1995). "Exchange-rate pass-through", Journal of Economic Surveys, 9, pp. 197-231.

[21] OBSTFELD, M. (2002). "Inflation Targeting, Exchange-Rate PassThrough and Volatility", American Economic Review, Papers and Proceedings, 92, pp. 102-107.

[22] OLIVEI, G. (2002). "Exchange rates and the prices of manufacturing products imported into the United States", New England Economic Review, First quarter, Federal Reserve Bank of Boston, pp. 3-8. 
[23] OTANI, A., S. SHIRATSUKA and T. SHIROTA (2006). "Revisiting the Decline in the Exchange Rate Pass-Through: Further Evidence from Japan's Import Prices", Monetary and Economic Studies, Institute for Monetary and Economic Studies, vol. 24 (1), March, Bank of Japan, pp. 61-75.

[24] PEDRONI, P. (1999). "Critical Values for Cointegration Tests in Heterogeneous Panels with Multiple Regressors", Oxford Bulletin of Economics and Statistics, Special Issue, pp. 653-670.

[25] SEKINE, T. (2006). Time-varying exchange rate pass-through: experiences of some industrial countries, BIS Working Papers No. 202, Bank of International Settlements.

[26] TAYLOR, J. B. (2001). "Low Inflation, pass-through, and the Pricing Power of Firms", European Economic Review, 44 (7), pp. 1389-1408.

[27] THOMAS, C. P., and J. MÁRQUEZ (2006). Measurement matters for modelling U.S. import prices, International Finance Discussion Papers No. 883, Board of Governors of the Federal Reserve System.

\section{Appendix I. Data}

Import Prices. The data are monthly unit value indices of imports from euro area countries of eight product categories for twelve countries (the Czech Republic, Cyprus, Latvia, Lithuania, Hungary, Malta, Poland, Slovakia, Bulgaria, Romania, Estonia and Turkey) from 2000:01 to 2007:06 extracted from COMEXT (eurostat). The data is not seasonally adjusted. I have used products at the 1-digit SITC level. The list of products is:

$\begin{array}{ll}\text { SITC } & \text { Product Category } \\ 0 & \text { Food and live animals } \\ 1 & \text { Beverages and Tobacco } \\ 2 & \text { Crude materials } \\ 3 & \text { Mineral fuels } \\ 4 & \text { Animal, vegetable oil, fat } \\ 5 & \text { Chemicals } \\ 6 & \text { Basic Manufactures } \\ 7 & \text { Vehicles and transport equipment } \\ 8 & \text { Manufactured goods }\end{array}$

Exchange rates. I consider the monthly exchange rate indices (period averages) expressed in units of domestic currency per unit of foreign currency from COMEXT (eurostat). 
Foregin Price Index. I use a monthly series of the world price of the product category from COMEX (eurostat). This world price is the $€$ price of the unit value index of imports of that product category coming from the euro area. 
Appendix II. Pass-Through elasticities in the short- and long-run

\begin{tabular}{|l|l|l|l|l|l|l|l|l|l|}
\hline $\begin{array}{c}\text { Country } \\
\text { Industry }\end{array}$ & $\mathbf{C Z}$ & $\mathbf{C Y}$ & $\mathbf{L V}$ & $\mathbf{H U}$ & $\mathbf{P L}$ & $\mathbf{S K}$ & $\mathbf{R U}$ & $\mathbf{T K}$ & $\mathbf{S L}$ \\
\hline $\mathbf{0 . S} / \mathbf{R}$ & 0.10 & 2.93 & 0.78 & 0.29 & 0.24 & $0.15^{\dagger}$ & $0.19^{\dagger}$ & $0.04^{\dagger}$ & 0.31 \\
\hline $\mathbf{0 . L} / \mathbf{R}$ & $0.71^{\dagger}$ & 5.43 & $0.63^{\dagger}$ & 0.52 & $0.47^{*}$ & 0.43 & $0.09^{\dagger}$ & $0.24^{* \dagger}$ & $0.48^{\dagger}$ \\
\hline $\mathbf{1 . S} / \mathbf{R}$ & $0.89^{\dagger}$ & 3.99 & $3.39^{*}$ & 0.11 & $0.82^{*}$ & $2.02^{* \dagger}$ & $0.12^{\dagger}$ & $0.05^{\dagger}$ & 0.56 \\
\hline $\mathbf{1 . L} / \mathbf{R}$ & $0.25^{\dagger}$ & 0.38 & 1.77 & $1.12^{* \dagger}$ & 0.96 & 0.66 & $0.39^{\dagger}$ & $0.06^{\dagger}$ & $0.94^{\dagger}$ \\
\hline $\mathbf{2 . S} \mathbf{R}$ & 0.27 & 2.26 & $0.32^{\dagger}$ & 0.14 & $0.11^{\dagger}$ & $0.21^{\dagger}$ & $0.10^{\dagger}$ & $0.07^{\dagger}$ & 0.59 \\
\hline $\mathbf{2 . L} / \mathbf{R}$ & 0.44 & 0.42 & $0.18^{\dagger}$ & $0.06^{* \dagger}$ & $0.07^{*}$ & $0.03^{\dagger}$ & $0.26^{\dagger}$ & $0.10^{\dagger}$ & 1.40 \\
\hline $\mathbf{3 . S} / \mathbf{R}$ & $0.35^{\dagger}$ & - & 0.85 & $1.03^{*}$ & $0.20^{*}$ & $0.05^{\dagger}$ & 0.10 & 0.53 & $14.68^{* \dagger}$ \\
\hline $\mathbf{3 . L} / \mathbf{R}$ & 0.37 & - & 0.32 & 0.16 & $0.05^{\dagger}$ & 0.21 & 0.30 & $0.04^{\dagger}$ & 1.35 \\
\hline $\mathbf{4 . S} / \mathbf{R}$ & $0.03^{\dagger}$ & - & - & 0.84 & $0.64^{\dagger}$ & $1.23^{*}$ & 0.52 & $0.03^{\dagger}$ & 5.32 \\
\hline $\mathbf{4 . L} / \mathbf{R}$ & 0.05 & - & - & $1.51^{\dagger}$ & $0.05^{*}$ & 1.35 & 0.96 & $0.32^{\dagger}$ & 0.38 \\
\hline $\mathbf{5 . S} / \mathbf{R}$ & $0.30^{\dagger}$ & 1.02 & 0.93 & $0.12^{\dagger}$ & $0.01^{\dagger}$ & $0.46^{* \dagger}$ & $0.20^{\dagger}$ & $0.003^{\dagger}$ & 0.01 \\
\hline $\mathbf{5 . L / R}$ & $0.57^{\dagger}$ & 0.03 & 1.77 & $0.55^{\dagger}$ & $0.07^{\dagger}$ & 0.19 & $0.42^{\dagger}$ & $0.006^{\dagger}$ & 0.30 \\
\hline $\mathbf{6 . S} / \mathbf{R}$ & $0.05^{\dagger}$ & 3.59 & $0.35^{\dagger}$ & $0.02^{\dagger}$ & $0.12^{\dagger}$ & $0.10^{\dagger}$ & $0.24^{* \dagger}$ & $0.05^{* \dagger}$ & $0.45^{\dagger}$ \\
\hline $\mathbf{6 . L} / \mathbf{R}$ & $0.05^{\dagger}$ & 0.59 & $0.08^{\dagger}$ & $0.15^{\dagger}$ & $0.19^{\dagger}$ & $0.25^{\dagger}$ & $0.43^{\dagger}$ & $0.03^{\dagger}$ & $0.30^{\dagger}$ \\
\hline $\mathbf{7 . S} / \mathbf{R}$ & $0.002^{\dagger}$ & 4.86 & $0.42^{\dagger}$ & $0.24^{\dagger}$ & $0.03^{\dagger}$ & $0.30^{* \dagger}$ & $0.25^{* \dagger}$ & $0.01^{\dagger}$ & 0.77 \\
\hline $\mathbf{7 . L} / \mathbf{R}$ & $0.15^{\dagger}$ & 4.83 & 0.96 & $0.19^{\dagger}$ & $0.22^{\dagger}$ & $0.05^{\dagger}$ & $0.57^{\dagger}$ & $0.05^{\dagger}$ & 0.20 \\
\hline $\mathbf{8 . S} / \mathbf{R}$ & $0.12^{\dagger}$ & 1.75 & $0.23^{\dagger}$ & $0.13^{\dagger}$ & $0.10^{\dagger}$ & $0.01^{\dagger}$ & $0.05^{\dagger}$ & $0.03^{\dagger}$ & 1.04 \\
\hline $\mathbf{8 . L} / \mathbf{R}$ & 0.17 & 4.08 & $0.34^{\dagger}$ & $0.12^{\dagger}$ & $0.24^{\dagger}$ & $0.09^{\dagger}$ & $0.02^{\dagger}$ & $0.07^{\dagger}$ & 1.44 \\
\hline
\end{tabular}

Source: Eurostat and own calculations. ${ }^{*, \dagger}$ It can be statistically rejected that the pass-through is zero/one.

CZ Czech Republic, CY Cyprus, LV latvia,

HU Hungary,PL P Poland,SK Slovakia,

RU Romania,TK $\sim$ Turkey,SL $\sim$ Slovenia 


\section{BANCO DE ESPAÑA PUBLICATIONS}

\section{WORKING PAPERS ${ }^{1}$}

0701 PRAVEEN KUJAL AND JUAN RUIZ: Cost effectiveness of R\&D and strategic trade policy.

0702 MARÍA J. NIETO AND LARRY D. WALL: Preconditions for a successful implementation of supervisors' prompt corrective action: Is there a case for a banking standard in the EU?

0703 PHILIP VERMEULEN, DANIEL DIAS, MAARTEN DOSSCHE, ERWAN GAUTIER, IGNACIO HERNANDO, ROBERTO SABBATINI AND HARALD STAHL: Price setting in the euro area: Some stylised facts from individual producer price data.

0704 ROBERTO BLANCO AND FERNANDO RESTOY: Have real interest rates really fallen that much in Spain?

0705 OLYMPIA BOVER AND JUAN F. JIMENO: House prices and employment reallocation: International evidence.

0706 ENRIQUE ALBEROLA AND JOSÉ M. a SERENA: Global financial integration, monetary policy and reserve accumulation. Assessing the limits in emerging economies.

0707 ÁNGEL LEÓN, JAVIER MENCÍA AND ENRIQUE SENTANA: Parametric properties of semi-nonparametric distributions, with applications to option valuation.

0708 ENRIQUE ALBEROLA AND DANIEL NAVIA: Equilibrium exchange rates in the new EU members: external imbalances vs. real convergence.

0709 GABRIEL JIMÉNEZ AND JAVIER MENCÍA: Modelling the distribution of credit losses with observable and latent factors.

0710 JAVIER ANDRÉS, RAFAEL DOMÉNECH AND ANTONIO FATÁS: The stabilizing role of government size.

0711 ALFREDO MARTÍN-OLIVER, VICENTE SALAS-FUMÁS AND JESÚS SAURINA: Measurement of capital stock and input services of Spanish banks.

0712 JESÚS SAURINA AND CARLOS TRUCHARTE: An assessment of Basel II procyclicality in mortgage portfolios.

0713 JOSÉ MANUEL CAMPA AND IGNACIO HERNANDO: The reaction by industry insiders to M\&As in the European financial industry.

0714 MARIO IZQUIERDO, JUAN F. JIMENO AND JUAN A. ROJAS: On the aggregate effects of immigration in Spain.

0715 FABIO CANOVA AND LUCA SALA: Back to square one: identification issues in DSGE models.

0716 FERNANDO NIETO: The determinants of household credit in Spain.

0717 EVA ORTEGA, PABLO BURRIEL, JOSÉ LUIS FERNÁNDEZ, EVA FERRAZ AND SAMUEL HURTADO: Update of the quarterly model of the Bank of Spain. (The Spanish original of this publication has the same number.)

0718 JAVIER ANDRÉS AND FERNANDO RESTOY: Macroeconomic modelling in EMU: how relevant is the change in regime?

0719 FABIO CANOVA, DAVID LÓPEZ-SALIDO AND CLAUDIO MICHELACCI: The labor market effects of technology shocks.

0720 JUAN M. RUIZ AND JOSEP M. VILARRUBIA: The wise use of dummies in gravity models: Export potentials in the Euromed region.

0721 CLAUDIA CANALS, XAVIER GABAIX, JOSEP M. VILARRUBIA AND DAVID WEINSTEIN: Trade patterns, trade balances and idiosyncratic shocks.

0722 MARTÍN VALLCORBA AND JAVIER DELGADO: Determinantes de la morosidad bancaria en una economía dolarizada. El caso uruguayo.

0723 ANTÓN NÁKOV AND ANDREA PESCATORI: Inflation-output gap trade-off with a dominant oil supplier.

0724 JUAN AYUSO, JUAN F. JIMENO AND ERNESTO VILLANUEVA: The effects of the introduction of tax incentives on retirement savings.

0725 DONATO MASCIANDARO, MARÍA J. NIETO AND HENRIETTE PRAST: Financial governance of banking supervision.

0726 LUIS GUTIÉRREZ DE ROZAS: Testing for competition in the Spanish banking industry: The Panzar-Rosse approach revisited.

0727 LUCÍA CUADRO SÁEZ, MARCEL FRATZSCHER AND CHRISTIAN THIMANN: The transmission of emerging market shocks to global equity markets.

0728 AGUSTÍN MARAVALL AND ANA DEL RÍO: Temporal aggregation, systematic sampling, and the Hodrick Prescott filter.

0729 LUIS J. ÁLVAREZ: What do micro price data tell us on the validity of the New Keynesian Phillips Curve?

0730 ALFREDO MARTÍN-OLIVER AND VICENTE SALAS-FUMÁS: How do intangible assets create economic value? An application to banks.

0731 REBECA JIMÉNEZ-RODRÍGUEZ: The industrial impact of oil price shocks: Evidence from the industries of six OECD countries.

0732 PILAR CUADRADO, AITOR LACUESTA, JOSÉ MARÍA MARTÍNEZ AND EDUARDO PÉREZ: El futuro de la tasa de actividad española: un enfoque generacional.

0733 PALOMA ACEVEDO, ENRIQUE ALBEROLA AND CARMEN BROTO: Local debt expansion... vulnerability reduction? An assessment for six crises-prone countries.

0734 PEDRO ALBARRÁN, RAQUEL CARRASCO AND MAITE MARTÍNEZ-GRANADO: Inequality for wage earners and self-employed: Evidence from panel data.

1. Previously published Working Papers are listed in the Banco de España publications catalogue. 
0735 ANTÓN NÁKOV AND ANDREA PESCATORI: Oil and the Great Moderation.

0736 MICHIEL VAN LEUVENSTEIJN, JACOB A. BIKKER, ADRIAN VAN RIXTEL AND CHRISTOFFER KOK-SØRENSEN: A new approach to measuring competition in the loan markets of the euro area.

0737 MARIO GARCÍA-FERREIRA AND ERNESTO VILLANUEVA: Employment risk and household formation: Evidence from differences in firing costs.

0738 LAURA HOSPIDO: Modelling heterogeneity and dynamics in the volatility of individual wages.

0739 PALOMA LÓPEZ-GARCÍA, SERGIO PUENTE AND ÁNGEL LUIS GÓMEZ: Firm productivity dynamics in Spain.

0740 ALFREDO MARTÍN-OLIVER AND VICENTE SALAS-FUMÁS: The output and profit contribution of information technology and advertising investments in banks.

0741 ÓSCAR ARCE: Price determinacy under non-Ricardian fiscal strategies.

0801 ENRIQUE BENITO: Size, growth and bank dynamics.

0802 RICARDO GIMENO AND JOSÉ MANUEL MARQUÉS: Uncertainty and the price of risk in a nominal convergence process.

0803 ISABEL ARGIMÓN AND PABLO HERNÁNDEZ DE COS: Los determinantes de los saldos presupuestarios de las Comunidades Autónomas.

0804 OLYMPIA BOVER: Wealth inequality and household structure: US vs. Spain.

0805 JAVIER ANDRÉS, J. DAVID LÓPEZ-SALIDO AND EDWARD NELSON: Money and the natural rate of interest: structural estimates for the United States and the euro area.

0806 CARLOS THOMAS: Search frictions, real rigidities and inflation dynamics.

0807 MAXIMO CAMACHO AND GABRIEL PEREZ-QUIROS: Introducing the EURO-STING: Short Term INdicator of Euro Area Growth.

0808 RUBÉN SEGURA-CAYUELA AND JOSEP M. VILARRUBIA: The effect of foreign service on trade volumes and trade partners.

0809 AITOR ERCE: A structural model of sovereign debt issuance: assessing the role of financial factors.

0810 ALICIA GARCÍA-HERRERO AND JUAN M. RUIZ: Do trade and financial linkages foster business cycle synchronization in a small economy?

0811 RUBÉN SEGURA-CAYUELA AND JOSEP M. VILARRUBIA: Uncertainty and entry into export markets.

0812 CARMEN BROTO AND ESTHER RUIZ: Testing for conditional heteroscedasticity in the components of inflation.

0813 JUAN J. DOLADO, MARCEL JANSEN AND JUAN F. JIMENO: On the job search in a model with heterogeneous jobs and workers.

0814 SAMUEL BENTOLILA, JUAN J. DOLADO AND JUAN F. JIMENO: Does immigration affect the Phillips curve? Some evidence for Spain

0815 ÓSCAR J. ARCE AND J. DAVID LÓPEZ-SALIDO: Housing bubbles.

0816 GABRIEL JIMÉNEZ, VICENTE SALAS-FUMÁS AND JESÚS SAURINA: Organizational distance and use of collateral for business loans.

0817 CARMEN BROTO, JAVIER DÍAZ-CASSOU AND AITOR ERCE-DOMÍNGUEZ: Measuring and explaining the volatility of capital flows towards emerging countries.

0818 CARLOS THOMAS AND FRANCESCO ZANETTI: Labor market reform and price stability: an application to the Euro Area.

0819 DAVID G. MAYES, MARÍA J. NIETO AND LARRY WALL: Multiple safety net regulators and agency problems in the EU: Is Prompt Corrective Action partly the solution?

0820 CARMEN MARTÍNEZ-CARRASCAL AND ANNALISA FERRANDO: The impact of financial position on investment: an analysis for non-financial corporations in the euro area.

0821 GABRIEL JIMÉNEZ, JOSÉ A. LÓPEZ AND JESÚS SAURINA: Empirical analysis of corporate credit lines.

0822 RAMÓN MARÍA-DOLORES: Exchange rate pass-through in new Member States and candidate countries of the EU.

\begin{tabular}{|r|c|}
\hline & Unidad de Publicaciones \\
BANCODEESPANA & Alcalá, 522; 28027 Madrid \\
Eurosistema & Telephone +34 91 338 6363. Fax +34913386488 \\
& e-mail: publicaciones@bde.es \\
www.bde.es
\end{tabular}

